\title{
Program Evaluation - Automotive Lightweighting Materials Program Research and Development Projects Assessment of Benefits - Case Studies No. 2
}

September 2002

Prepared by

Sujit Das

Engineering Science and Technology Division

Oak Ridge National Laboratory

Jean H. Peretz

Energy, Environment and Resources Center

The University of Tennessee

Bruce E. Tonn

Environmental Sciences Division

Oak Ridge National Laboratory 


\title{
DOCUMENT AVAILABILITY
}

Reports produced after January 1,1996, are generally available free via the U.S. Department of Energy (DOE) Information Bridge.

Web site http://www.osti.gov/bridge

Reports produced before January 1, 1996, may be purchased by members of the public from the following source.

\author{
National Technical Information Service \\ 5285 Port Royal Road \\ Springfield, VA 22161 \\ Telephone 703-605-6000 (1-800-553-6847) \\ TDD 703-487-4639 \\ Fax 703-605-6900 \\ E-mail info@ntis.fedworld.gov \\ Web site http://www.ntis.gov/support/ordernowabout.htm
}

Reports are available to DOE employees, DOE contractors, Energy Technology Data Exchange (ETDE) representatives, and International Nuclear Information System (INIS) representatives from the following source.

Office of Scientific and Technical Information

P.O. Box 62

Oak Ridge, TN 37831

Telephone 865-576-8401

Fax 865-576-5728

E-mail reports@adonis.osti.gov

Web site http://www.osti.gov/contact.html

This report was prepared as an account of work sponsored by an agency of the United States Government. Neither the United States government nor any agency thereof, nor any of their employees, makes any warranty, express or implied, or assumes any legal liability or responsibility for the accuracy, completeness, or usefulness of any information, apparatus, product, or process disclosed, or represents that its use would not infringe privately owned rights. Reference herein to any specific commercial product, process, or service by trade name, trademark, manufacturer, or otherwise, does not necessarily constitute or imply its endorsement, recommendation, or favoring by the United States Government or any agency thereof. The views and opinions of authors expressed herein do not necessarily state or reflect those of the United States Government or any agency thereof. 


\title{
Program Evaluation - Automotive Lightweighting Materials Program Research and Development Projects Assessment of Benefits - Case Studies No. 2
}

\author{
Sujit Das \\ Engineering Science and Technology Division \\ Oak Ridge National Laboratory \\ Jean H. Peretz \\ Energy, Environment and Resources Center \\ The University of Tennessee \\ Bruce E. Tonn \\ Environmental Sciences Division \\ Oak Ridge National Laboratory
}

September 2002

Prepared for

Automotive Lightweighting Materials Program

Office of Advanced Automotive Technologies

of the

U.S. DEPARTMENT OF ENERGY

Prepared by

OAK RIDGE NATIONAL LABORATORY

P.O. Box 2008

Oak Ridge, TN 37831-6285

managed by

UT-BATTELLE, LLC

for the

U.S. DEPARTMENT OF ENERGY

under contract DE-AC05-00OR22725 



\section{CONTENTS}

LIST OF TABLES $\ldots \ldots \ldots \ldots \ldots \ldots \ldots \ldots \ldots \ldots \ldots \ldots \ldots \ldots \ldots \ldots \ldots$

LIST OF FIGURES $\ldots \ldots \ldots \ldots \ldots \ldots \ldots \ldots \ldots \ldots \ldots \ldots \ldots \ldots \ldots \ldots \ldots \ldots \ldots \ldots$

EXECUTIVE SUMMARY $\ldots \ldots \ldots \ldots \ldots \ldots \ldots \ldots \ldots \ldots \ldots \ldots \ldots \ldots \ldots$

1. INTRODUCTION $\ldots \ldots \ldots \ldots \ldots \ldots \ldots \ldots \ldots \ldots \ldots \ldots \ldots \ldots \ldots \ldots \ldots \ldots$

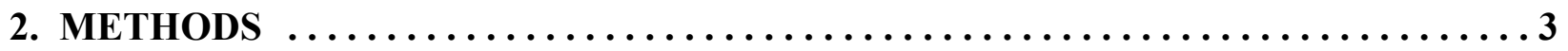

2.1 FEDERAL SUPPORT OF R\&D EXPENDITURES $\ldots \ldots \ldots \ldots \ldots \ldots \ldots \ldots$

2.2 REVIEW OF COMMONLY USED BENEFIT ESTIMATION

METHODS FOR PROGRAM EVALUATION $\ldots \ldots \ldots \ldots \ldots \ldots \ldots \ldots \ldots$

2.3 METHODS USED FOR ALM PROGRAM EVALUATION ..........

2.3.1 Qualitative Assessment ......................

2.3.2 National Research Council Indicators $\ldots \ldots \ldots \ldots \ldots \ldots \ldots \ldots$

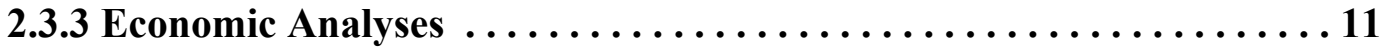

2.3.3.1. Benefit-cost Analysis . . . . . . . . . . . . . . . 11

2.3.3.2. Person-Year and Cost-Savings Analysis $\ldots \ldots \ldots \ldots \ldots$

2.4 NATIONAL ACADEMY OF SCIENCES FRAMEWORK FOR DOE

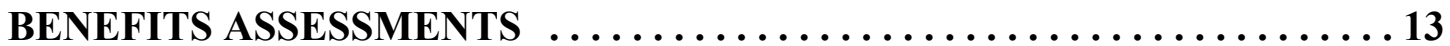

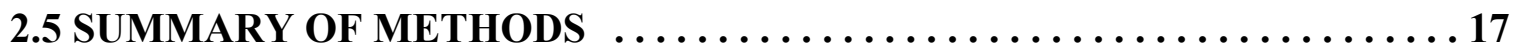

3. AUTOMOTIVE LIGHTWEIGHTING MATERIALS PROJECTS $\ldots \ldots \ldots \ldots$

3.1 DESIGN AND PRODUCT OPTIMIZATION FOR CAST

LIGHT METALS . . . . . . . . . . . . . . . . . . . . . . . . . 19

3.2 DURABILITY OF LIGHTWEIGHT COMPOSITE STRUCTURES . . . . . 20

3.3 RAPID TOOLING FOR FUNCTIONAL PROTOTYPING OF

METAL MOLD PROCESSES . . . . . . . . . . . . . . . . . 21

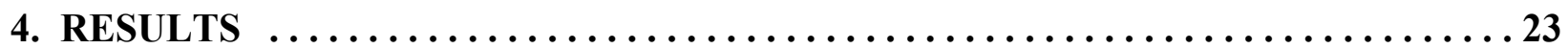

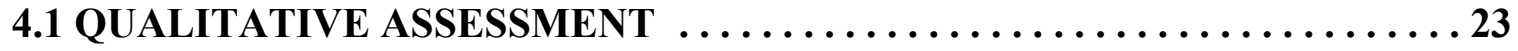

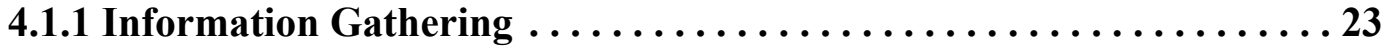

4.1.2 Design and Product Optimization for Cast Light Metals . . . . . . . 25

4.1.3 Durability of Lightweight Composite Structures $\ldots \ldots \ldots \ldots \ldots$

4.1.4 Rapid Tooling for Functional Prototyping of

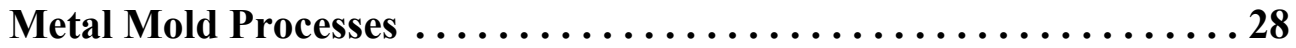

4.1.5 Summary of Qualitative Assessment .................. 29

4.2 NATIONAL RESEARCH COUNCIL INDICATORS ............ 30

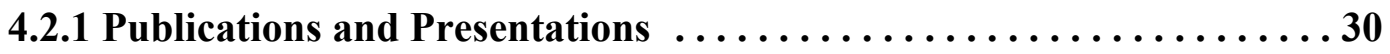

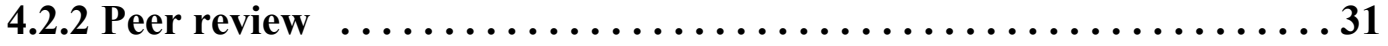

4.2.3 International Competition and Appropriate Indicators $\ldots \ldots \ldots \ldots 31$

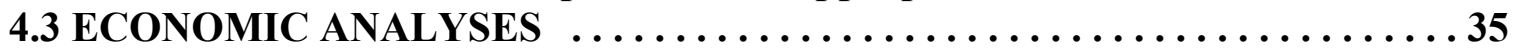




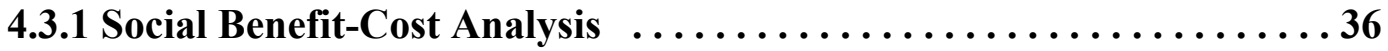

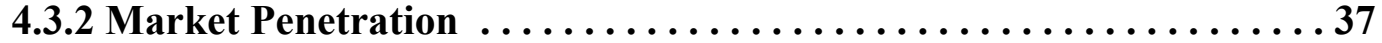

4.3.2.1 Design and Product Optimization for Cast Light Metals . . 37

4.3.2.2 Durability of Lightweight Composite Structures . . . . . . . 40

4.3.2.3 Rapid Tooling for Functional Prototyping of Metal

Mold Processes $\ldots \ldots \ldots \ldots \ldots \ldots \ldots \ldots \ldots \ldots \ldots \ldots \ldots$

4.3.3 Energy, Environmental, and Security Benefits $\ldots \ldots \ldots \ldots \ldots \ldots \ldots$

4.3.4 Market Penetration Benefit Estimates $\ldots \ldots \ldots \ldots \ldots \ldots \ldots \ldots . \ldots 48$

4.3.5 Benefit-Cost Ratios ....................... 50

4.3.6 Person-Year and Cost Savings Analysis $\ldots \ldots \ldots \ldots \ldots \ldots \ldots \ldots$

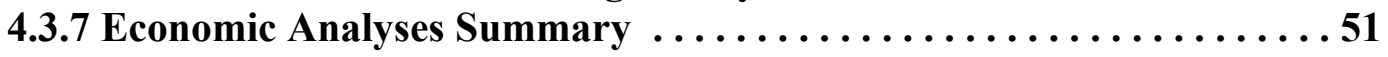

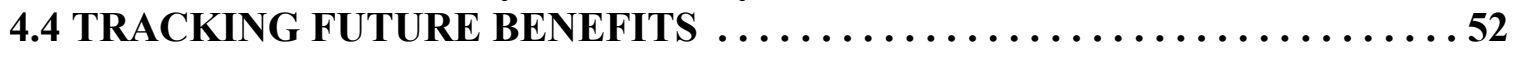

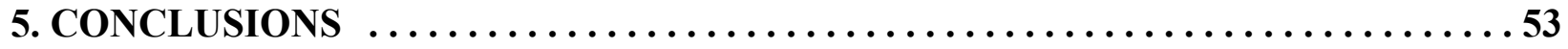

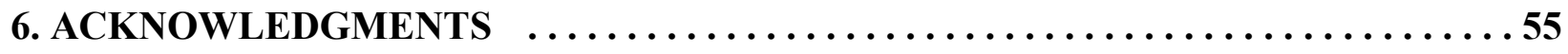

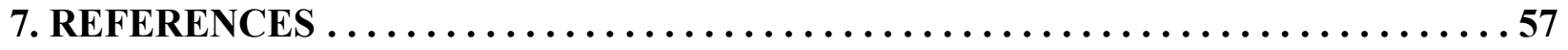

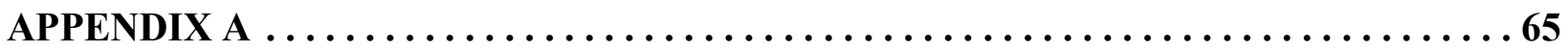

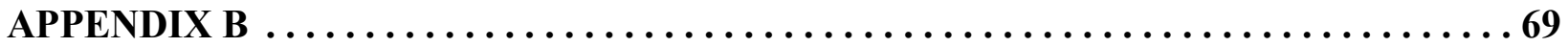




\section{LIST OF TABLES}

Table E.S. 1. Summary of Qualitative Assessments $\ldots \ldots \ldots \ldots \ldots \ldots \ldots \ldots \ldots$ vii

Table E.S. 2. National Research Council Indicators $\ldots \ldots \ldots \ldots \ldots \ldots \ldots \ldots$. . . . . viii

Table E.S. 3. Social Benefit-cost Ratios $\ldots \ldots \ldots \ldots \ldots \ldots \ldots \ldots \ldots \ldots \ldots \ldots \ldots \ldots$

Table 2.1. Evaluation Methods Commonly Used $\ldots \ldots \ldots \ldots \ldots \ldots \ldots \ldots \ldots$

Table 2.2. NAS Matrix for Assessing Benefits and Costs $\ldots \ldots \ldots \ldots \ldots \ldots \ldots \ldots$

Table 2.3. NAS Derivation of Columns for the Benefits Matrix $\ldots \ldots \ldots \ldots \ldots \ldots$

Table 2.4. Lee et al. Modification of NAS Framework $\ldots \ldots \ldots \ldots \ldots \ldots \ldots$

Table 2.5. Comparison of NAS Framework and Das, Peretz and Tonn Framework .. 17

Table 2.6. Evaluation Methods Used in this Research $\ldots \ldots \ldots \ldots \ldots \ldots \ldots$

Table 4.1. Response Rates for Analysis $\ldots \ldots \ldots \ldots \ldots \ldots \ldots \ldots \ldots \ldots \ldots$

Table 4.2. Summary of Qualitative Assessments $\ldots \ldots \ldots \ldots \ldots \ldots \ldots \ldots \ldots$

Table 4.3. Responses to Importance of R\&D Project to Competitiveness of Firms Involved in R\&D Project . . . . . . . . . . . . . . . 33

Table 4.5. National Research Council Indicators $\ldots \ldots \ldots \ldots \ldots \ldots \ldots \ldots \ldots$

Table 4.6. Five-Year Aluminum Castings Forecast of Cast Light Metals Project ... . 39

Table 4.7. Five-Year Composites Forecasts of Durability Composites Project ...... 42

Table 4.8. Five-Year Automotive Die Castings Forecasts of Rapid Tooling Project . . 44

Table 4.9. Energy and Environmental Savings Per Pound of

Material Used to Replace Steel ....................... 46

Table 4.10. Energy and Environmental Emission Values Scenarios $\ldots \ldots \ldots \ldots \ldots$

Table 4.11. Energy, Environmental, and Security Benefit Results . . . . . . . . . . 49

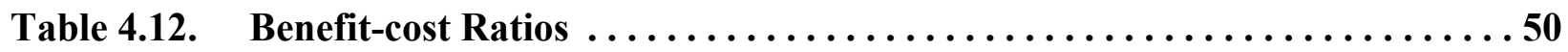

Table 4.13. Person-Year and Cost Savings Benefit Estimates $\ldots \ldots \ldots \ldots \ldots \ldots \ldots \ldots$ 


\section{LIST OF FIGURES}

Figure 4.1. Aluminum Castings Forecast of Cast Light Metals . . . . . . . . . . . 39

Figure 4.2. Composites Forecasts of Durability of Composites $\ldots \ldots \ldots \ldots \ldots \ldots$

Figure 4.3. Die Castings Forecasts of Rapid Tooling $\ldots \ldots \ldots \ldots \ldots \ldots \ldots \ldots \ldots$ 


\section{EXECUTIVE SUMMARY}

This report is the second of a series of studies to evaluate research and development (R\&D) projects funded by the Automotive Lightweighting Materials (ALM) Program of the Office of Advanced Automotive Technologies (OAAT) of the U.S. Department of Energy (DOE). ${ }^{1}$ The objectives of the program evaluation are to assess short-run outputs and long-run outcomes that may be attributable to the ALM R\&D projects. The ALM program focuses on the development and validation of advanced technologies that significantly reduce automotive vehicle body and chassis weight without compromising other attributes such as safety, performance, recyclability, and cost. Funded projects range from fundamental materials science research to applied research in production environments. Collaborators on these projects include national laboratories, universities, and private sector firms, such as leading automobile manufacturers and their suppliers.

Three ALM R\&D projects were chosen for this evaluation: Design and Product Optimization for Cast Light Metals, Durability of Lightweight Composite Structures, and Rapid Tooling for Functional Prototyping of Metal Mold Processes. These projects were chosen because they have already been completed. The first project resulted in development of a comprehensive cast light metal property database, an automotive application design guide, computerized predictive models, process monitoring sensors, and quality assurance methods.

The second project, the durability of lightweight composite structures, produced durability-based design criteria documents, predictive models for creep deformation, and minimum test requirements and suggested test methods for establishing durability properties and characteristics of random glass-fiber composites for automotive structural composites. The durability project supported Focal Project II, a validation activity that demonstrates ALM program goals and reduces the lead time for bringing new technology into the marketplace. Focal projects concentrate on specific classes of materials and nonproprietary components and are done jointly by DOE and the Automotive Composites Consortium of U.S. Council for Automotive Research (USCAR).

The third project developed a rapid tooling process that reduces tooling time, originally some 4852 weeks, to less than 12 weeks by means of rapid generation of die-casting die inserts and development of generic holding blocks, suitable for use with large casting applications. This project was conducted by the United States Automotive Materials Partnership, another USCAR consortium.

We chose an evaluation framework that would meet our goal of evaluating both short-run outputs and long-run outcomes of the R\&D projects. This framework addresses important

${ }^{1}$ Das, Peretz and Tonn, 2001, was the first report. 
aspects of the benefits of $R \& D$ projects, using both qualitative and quantitative measures. We used three methods to gauge the benefits attributable to ALM projects were chosen:

$<$ Qualitative Assessment. We collected and assessed participant views about the benefits of the projects. Questions addressed whether: the projects' technical objectives were met; the projects yielded new knowledge; the projects would have been conducted without federal support; and the projects enhanced collaboration among the participants. Answers to these questions indicated the immediate outputs of the R\&D projects.

$<$ National Research Council (NRC) Indicators. Participants' answers to prepared questions and project materials enumerated the number of publications associated with the projects, established whether the projects benefited from outside peer review, and helped us determine whether the projects enhanced U.S. international competitiveness. These answers indicated both near-term (e.g., number of publications produced by the end of a project) and long-run benefits (knowledge level gained through the publications, human capital investment in graduate students' dissertations and theses produced, and increased international competitiveness of the Big 3 automakers).

$<$ Economic Analyses. We conducted a benefit-cost analysis to monetize values for the benefits and costs of each project. While the benefits are due mainly to the commercialization of new technologies, companies also received benefits accruing from federal support. We developed forecasts of market penetration of new vehicles benefiting from the new technologies to the year 2025. The benefits are estimated based on the differential over the normal pace of technology adoption. Benefits examined include energy savings, reductions in air pollutants [e.g., carbon dioxide $\left(\mathrm{CO}_{2}\right)$, nitrogen oxides $\left(\mathrm{NO}_{\mathrm{x}}\right)$ ], and security benefits. We assigned values to each benefit, and estimated benefits and costs to the year 2025. We defined costs as DOE support and private sector cost sharing. We calculated net present values for the benefits. We also calculated the ratio of benefits to costs for each project. Second, we calculated monetized cost savings to industry by having access to federal R\&D resources.

Table E.S.1. below presents the results of the qualitative assessment. Overall, the qualitative assessment is very positive for the three projects. The projects met all technical objectives and all yielded new knowledge. In one case, the private sector participants indicated that they would not have participated in the R\&D effort without federal funding; in the other two cases, some participants would have proceeded with $R \& D$ but with considerably less funding. In all cases, collaboration among the participants was enhanced. The rapid tooling process is being used by one of the Big 3 automakers, and all Big 3 automakers are using to some degree the manuals developed under the durability of composite structures project. 
Table E.S.1. Summary of Qualitative Assessments

\begin{tabular}{|c|c|c|c|c|c|}
\hline Project & $\begin{array}{c}\text { Met technical } \\
\text { objectives? }\end{array}$ & $\begin{array}{l}\text { Yielded new } \\
\text { knowledge? }\end{array}$ & $\begin{array}{c}\text { Will technology } \\
\text { be } \\
\text { incorporated? }\end{array}$ & $\begin{array}{c}\text { Would } \\
\text { company } \\
\text { have } \\
\text { participated } \\
\text { without } \\
\text { federal } \\
\text { funding? }\end{array}$ & $\begin{array}{c}\text { Was } \\
\text { collaboration } \\
\text { enhanced? }\end{array}$ \\
\hline $\begin{array}{l}\text { Cast light } \\
\text { metals }\end{array}$ & Yes & Yes & Mixed & $\begin{array}{c}\text { Mixed. For } \\
\text { those who } \\
\text { would have, } \\
\text { not with as } \\
\text { many } \\
\text { resources. }\end{array}$ & Yes* \\
\hline $\begin{array}{l}\text { Durability of } \\
\text { composite } \\
\text { structures }\end{array}$ & Yes & Yes & Yes & $\begin{array}{l}\text { Mixed. For } \\
\text { those who } \\
\text { would have, } \\
\text { not with as } \\
\text { many } \\
\text { resources. }\end{array}$ & Yes \\
\hline $\begin{array}{l}\text { Rapid tooling } \\
\text { process }\end{array}$ & Yes & Yes & Yes & No & Yes* \\
\hline
\end{tabular}

*Source: Fitzsimmons, 2001, see pages 98-102.

Table E.S.2. presents the results of the approach suggested by the National Academy of Sciences' (NAS) National Research Council for evaluating the benefits of federal R\&D programs. The number of publications varied considerably based primarily on number of private sector partners involved in the R\&D effort. Some 32 organizations collaborated in the cast light metals project, while only one national laboratory and the Big 3 automakers joined in the durability of composite structures project.

As we found in our previous analysis, none of the projects had outside review panels, although the projects did have the benefit of steering committee review. In 2001, however, an independent outside panel reviewed the ALM program within DOE, and NAS recently evaluated FreedomCAR's predecessor, the Partnership for a New Generation of Vehicles (PNGV) program (NAS, 2001b).

The study participants perceived that each R\&D project improved U.S. international competitiveness. They also felt that the United States is leading in R\&D for the durability of composite structures, while it is behind in cast light metals R\&D. They held mixed views of whether the United States is leading in research in rapid tooling processes. 
Table E.S.2. National Research Council Indicators

\begin{tabular}{lcccc}
\hline \multicolumn{1}{c}{ Project } & $\begin{array}{c}\text { Number of } \\
\text { publications } \\
\text { produced. }\end{array}$ & $\begin{array}{c}\text { Did it use an } \\
\text { outside review } \\
\text { panel? }\end{array}$ & $\begin{array}{c}\text { Did it improve } \\
\text { U.S. } \\
\text { international } \\
\text { competitiveness? }\end{array}$ & $\begin{array}{c}\text { Is the United } \\
\text { States leading in } \\
\text { research in this } \\
\text { field? }\end{array}$ \\
\hline $\begin{array}{l}\text { Cast light metals } \\
\begin{array}{l}\text { Durability of } \\
\text { composite } \\
\text { structures }\end{array}\end{array}$ & $44^{*}$ & No & Yes & No \\
$\begin{array}{l}\text { Rapid tooling } \\
\text { process }\end{array}$ & 35 & No & Yes & Yes \\
\hline
\end{tabular}

*Source: Fitzsimmons, 2001, see page 88.

Table E.S.3. presents the results of the benefit-cost analysis, taking into account energy, environmental, and security benefits. The project costs include both federal funding and private sector matching funds. Note that we estimated benefits based on the differential over the normal pace of technology adoption. In every case, the benefit-cost ratios indicate significant benefits for these projects. It must be noted, however, that several uncertainties are associated with these numbers, as is typical for benefit-cost analyses. First, the commercialization date and market penetration rates for each technology are uncertain. The analysis assumes dates for initial commercialization and market penetration rates that may or may not come true. Second, the projects reflect uncertainty in the level of benefits associated with each new vehicle that contains new lightweight materials. Third, uncertainties exist concerning the monetary values to be assigned to each benefit (e.g., values of reducing $\mathrm{CO}_{2}$, oil imports, etc.). Fourth, investment costs to be borne by the automobile manufacturers and their suppliers to implement the new technologies are not fully captured in this analysis. The base, moderate, and high cases in Table E.S.3. represent low, medium, and high monetary values for energy, environmental, and security savings. 
Table E.S.3. Social Benefit-cost Ratios

\begin{tabular}{lcccc}
\hline Project & $\begin{array}{c}\text { Project Cost } \\
\text { (\$ millions) }\end{array}$ & $\begin{array}{c}\text { B-C Ratio* } \\
\text { Base Case }\end{array}$ & $\begin{array}{c}\text { B-C Ratio* } \\
\text { Moderate Case }\end{array}$ & $\begin{array}{c}\text { B-C Ratio* } \\
\text { High Case }\end{array}$ \\
\hline Cast light metals & 5.91 & $46(39)^{*}$ & $69(49)^{*}$ & $78(56)^{*}$ \\
$\begin{array}{l}\text { Durability of composite } \\
\text { structures }\end{array}$ & 9.81 & $42(36)^{*}$ & $63(45)^{*}$ & $95(54)^{*}$ \\
Rapid tooling process & 2.71 & $143(121)^{*}$ & $211(150)^{*}$ & $245(172)^{*}$ \\
\hline
\end{tabular}

*Numbers inside parenthesis indicate benefit-cost ratios without taking into account environmental and security benefits.

Another measure of benefits, calculated in terms of person-years and cost savings gained by industry through having access to federal R\&D funding, ranged from an average of 2.4 to 7 years per firm involved in the R\&D project, with an average cost savings per firm ranging from $\$ 258,000$ to $\$ 1,225,000$. All three projects appear to have yielded substantial monetary benefits compared to their costs. 



\section{INTRODUCTION}

This report is the second of a series of studies to evaluate research and development (R\&D) projects funded by the Automotive Lightweighting Materials (ALM) Program of the Office of Advanced Automotive Technologies (OAAT) of the U.S. Department of Energy (DOE). ${ }^{2}$ The objectives of this program evaluation are to identify short-run outputs and long-run outcomes that may be attributable to the ALM R\&D projects. ${ }^{3}$ The ALM program focuses on the development and validation of advanced technologies that significantly reduce automotive vehicle body and chassis weight without compromising other attributes such as safety, performance, recyclability, and cost. Funded projects range from fundamental materials science research to applied research in production environments. Collaborators on these projects include national laboratories, universities, and private sector firms, such as leading automobile manufacturers and their suppliers.

There are several uses of program evaluations. Program evaluations of R\&D projects can provide informative feedback to project managers and program directors on whether $R \& D$ objectives were met. In this case, the evaluation can inform DOE and other program managers about how well ALM projects are contributing to the goals of an effective federal government/private sector collaborative effort to produce new, highly fuel efficient automobiles. They can also contribute to government-wide requirements for performance-based assessments, including R\&D projects, stipulated by the Government Performance and Results Act (GPRA) of 1993 (U.S. Congress, 1993).

Although program evaluations are not a trivial exercise, there is an increased effort to conduct evaluations of public R\&D expenditures. There are growing pressures to document effectiveness, efficiency, and accountability in all federal agencies, including those with R\&D functions. These sources include the Customer Service Executive Order of 1993; REGO III of the National Performance Review of 1996, the Federal Managers Financial Integrity Act of 1982; the Chief Financial Officers Act of 1990; the Government Management Reform Act of 1994; the Paperwork Reduction Act of 1995; and GPRA (Radin, 1998).

${ }^{2}$ Das, Peretz and Tonn, 2001, was the first report.

${ }^{3}$ We use the words results, outcomes, and benefits interchangeably in this report. Although the results of an $R \& D$ project may produce a technology that is not feasible for entry into the market place, considered potentially by many as a failure, we suggest as Radin (1998) succinctly points out, that "negative results are as important as positive ones" when evaluating federal R\&D projects. Moreover, as will be elaborated below, the National Academy of Sciences has specifically noted the role of markets in the introduction of new technology. 
Once evaluators determine the objectives of a program evaluation, evaluators can set out the methods or techniques that will measure those objectives. When selecting techniques for evaluating R\&D program benefits, several issues should be considered in light of the overall objectives. For example, when the objective is a long-term assessment of R\&D benefits: (1) Benefits may not be observed for many years after a project's funding ends (Ernst, 1998; Rouse, Boff and Thomas, 1997). (2) Unexpected benefits may accure, just as consequences may result from government programs (Gelijns, Rosenberg and Moskowitz, 1998; Brown and Wilson, 1993). (3) Some results are not monetary, e.g., increased knowledge even when a technology did not work (Nelson and Winter, 1982; Brown, 1998). (4) Benefits as well as costs may be distributed among a wide variety of interested parties with differing values, concerns and priorities (Rouse, Boff and Thomas, 1997). These factors grow in significance because they are observed in a diversity of R\&D spheres (Gibson and Rogers, 1994; National Research Council (NRC), 1994).

Several studies have taken on the challenge of evaluating R\&D projects. Moreover, methodologies for evaluating R\&D benefits for DOE specifically are evolving. Since the publication of our first report on ALM (Das, Peretz and Tonn, 2001), two additional methodological frameworks have been proposed (National Academy of Sciences(NAS), 2001a; Lee et al., 2002).

Section 2 of this report begins with a review of the literature about methods that have been used to evaluate government programs generally and then R\&D programs specifically. The second part of this section presents the three methods applied by this research to evaluate the benefits of ALM R\&D projects. Section 3 describes the three ALM projects we evaluated. Our first report focused on projects at different commercialization stages of technology development, while this assessment focuses on projects that have already been completed and are related to basic material design and technological issues. Section 4 presents the results of applying the methods to evaluate the three projects. Section 5 offers conclusions and suggestions for future research in this area. 


\section{METHODS}

\subsection{FEDERAL SUPPORT OF R\&D EXPENDITURES}

In 1996, the U.S. federal government spent $\$ 62$ billion on research and development (R\&D), including funds from the U.S. Department of Energy's budget (U.S. General Accounting Office (GAO), 1997). For DOE's R\&D energy research alone, from 1978 through 1999, the U.S. federal government spent $\$ 85$ billion on R\&D (NAS, 2001a). This public support of R\&D across all federal agencies continues a tradition that began in the mid to late 1800s (Nelson, Peck and Kalachek, 1967).

The rationale for government $\mathrm{R} \& \mathrm{D}$ expenditures includes the need for solutions to problems that are of general public interest (e.g., health, national security), an urgent need for private sector research and development support (e.g., agriculture), and the need for science and technology research beyond a particular public sector function or industry (e.g., the National Science Foundation's support for basic research) (Scherer, 1965; Nelson, Peck and Kalachek, 1967). ${ }^{4}$ There also is the often overlooked issue of investment in human capital development (NAS, 1999). Moreover, because of the high degree of uncertainty on investment returns or potential losses, the private sector often turns to the federal government for R\&D financial support (Scherer, 1965; Nelson and Winter, 1982; Gelijns, Rosenberg and Moskowitz, 1998).

Potential benefits derived from federal R\&D initiatives are quite numerous. These include advances in knowledge of fundamental science (Gelijns, Rosenberg and Moskowitz, 1998; Fitzsimmons, 2001); improvements in technologies (Mowery and Nelson, 1999; Ernst, 1998; Chapman, 1999); increased understanding and insights about policies, reduced production costs, improvements or modifications in products and processes (Hamilton and Sunding, 1998; Alston and Beach 1996); and facilitation of collaborative efforts (Dietz, 1997; Torpey, 1994). In addition, there is often educational support for undergraduate and graduate students (National Academy of Sciences (NAS, 1999). Finally, increased international competitiveness for U.S. firms may result from R\&D projects (Papadakis and Link, 1997). ALM projects funded through OAAT have the potential to provide all these types of benefits.

The ALM Program is a collaborative effort among DOE, national laboratories, the automotive industry, and academia. The overriding goals of the program are to promote energy efficiency and strengthen the international competitiveness of the U.S. automobile industry (see http://www.uscar.org/uscar/uscarmain.htm, accessed 7/09/02). The working assumptions are (1) that consumers will demand vehicles that are more energy efficient, cost less to use, and emit less greenhouse gases; and (2) that these new vehicles must be comparable in every other way to

${ }^{4} \mathrm{We}$ could also frame these within a market-failure economic context. For literature from this perspective, see for example Scherer (1965). 
more conventional vehicles. The ALM program seeks to make vehicles more energy efficient by making the vehicles lighter.

While automakers recognize that there are multitude of technological options to make vehicles lighter, they have also identified a corresponding number of associated R\&D issues. The automotive industry admits that it needs assistance in tackling issues such as automotive lightweighting R\&D (http://www.uscar.org/index.htm, accessed 7/09/02). Although the automotive industry has an active R\&D component, most of those funds are devoted to core business issues, i.e., designing new products and new product features. Additionally, many lightweighting R\&D issues cut across and through the industry, making them unlikely to be funded by single companies. For example, some R\&D focuses on production and processing of aluminum. Automobile manufacturers might use more aluminum in their vehicles if the costs of aluminum were lower and if aluminum parts could be made more reliable. However, the Big 3 automakers are not in the aluminum business; their suppliers are. The aluminum suppliers may have fewer research dollars to conduct basic and applied R\&D and may be unlikely to take such risks unless their automotive industry customers make a commitment to aluminum vehicles. Federal support for aluminum R\&D helps to overcome this structural catch-22 situation, and the national laboratories contribute unique R\&D capabilities and facilities not found in the private sector.

The ALM program is not in the business of choosing winners and losers. All projects are jointly decided by the major partners in a collaboration, e.g., DOE, the national laboratories, and automotive industry partners. Only those projects that could potentially benefit industry, as determined by industry, receive federal support. Sometimes, the projects allow the United States to maintain international leadership in an important area or make up ground lost to international competitors. Additionally, the national laboratories avoid compromising the sanctity of the marketplace. The national laboratories, with the cooperation of industry, only take an R\&D effort so far before allowing industry to commercialize a new material or process as the marketplace dictates.

Multiple benefits can accrue from ALM R\&D projects. These include human capital development through support for undergraduate and graduate students; knowledge benefits through publications; energy, environmental, and security benefits from lighter weight vehicles; and public health benefits through reduced environmental emissions.

\subsection{REVIEW OF COMMONLY USED BENEFIT ESTIMATION METHODS FOR PROGRAM EVALUATION}

The literature on the evaluation of governmental programs, including $R \& D$, is quite extensive. Five basic elements of any government program should be considered during a program evaluation (Hendrick, 1994): 
1. inputs,

2. processes,

3. outputs,

4. short-run impacts, and

5. long-run impacts.

Under this framework, inputs are the resources used for the program (i.e., fiscal, staff). Processes are activities performed in providing services, such as number of grant applications mailed. Program outputs are immediate results of the processes (i.e., number of grant applications reviewed). Short-run impacts would be the number of projects funded and whether the project objectives were met. Long-run impacts would be the increased knowledge level (intellectual) or, as in this case, reduced energy consumption from the purchase and use of lightweight vehicles.

Some scholars use the term short-run impacts, while others use the term short-term outputs, considering outputs as whether the objectives of the project were met (measured in either qualitative or quantitative terms). Similarly, some scholars use the term long-run impacts, others use the term long-run outcomes.

Others have thought of program evaluation in simpler terms; evaluation of needs, processes, and outcomes (Posavac and Carey, 1985). This collapsed version of what was presented by Hendrick in essence renames inputs as needs, combines processes and outputs, and does not specifically distinguish short-term versus long-term outcomes.

When evaluating federal R\&D programs, the objectives generally concentrate on outputs and outcomes while acknowledging that inputs and processes are influential in outputs and outcomes. In this context of evaluating ALM R\&D projects, we consider short-run outputs as those that can be measured qualitatively or quantitatively and assess whether the R\&D project's objectives were met. Outcomes are an assessment of the results of a program compared to its intended purposes; for example, will lighter weight vehicles be introduced into the marketplace through technology development funded through ALM projects?

Our definitions of outputs and outcomes are supported by the program evaluation literature and by definitions included in recent federal performance legislation (see, for example, Link and Scott, 1998). Outcomes of government spending, either on R\&D or in broader terms, seek to examine the impacts on the general public from expenditures of limited resources. In the latest round of government performance reforms, specifically GPRA, the attention centers on "measurement and systematic analysis"of whether Federal programs achieve intended objectives (GPRA, Section 4, 1993). By focusing on results, we emphasize program effectiveness and public accountability and determine whether positive outcomes are indeed accruing to the general public. In other words, is there a positive difference in people's lives from the federal government's involvement in R\&D programs (Radin, 1998; U.S. GAO, 1997; NAS, 1999)?

Previous studies have used numerous methods to evaluate federal R\&D expenditures. A brief description of these methods follows; more detailed information is presented in Appendix A. 
These methods, of course, are predicated on the objectives of the program evaluation and include:

1. Economics. Economic measures are frequently used by federal agencies in their evaluations of R\&D investments. These techniques may take different forms, but the most common are benefit-to-cost ratio, internal rate of return, present value of net savings, and net benefits (e.g., a measure of rate of return). Weaknesses to economic techniques include insufficient data on benefits and/or costs, time lags between R\&D funding and beneficial outcomes, marginal rate of return (how much return for an extra dollar of investment), and complexity of innovation with multiple inputs required for full adoption. Regardless of the weaknesses, economic techniques are frequently used.

2. Bibliometrics. Bibliometrics is the analysis of output from research using publication-based data. Forms of bibliometrics include publications, citation counts, presentations at conferences, publication of conference proceedings, and technical reports that are publicly available (e.g., from national laboratories). Limitations on use of publications as a tool include measurements of quality versus quantity in publication outlets (e.g., whether conference proceedings are peer reviewed or how well-regarded a journal is in a particular discipline), challenges in comparisons across disciplinary fields, and the increasingly important role of interdisciplinary research seeking appropriate publication outlets. Patents vary across technologies and industries, which hinders comparisons among projects.

3. Case studies. Case studies focus on the institutional, organizational, and technical factors that influence research processes, and provide in-depth insights into the success or failure of a research project. Traditionally, case studies have been used to gauge the linkages between R\&D and economic innovation and to judge whether R\&D projects meet policy objectives established for a group mandated to address linkages between R\&D and the economy (Kingsley, 1993). Yin (1984) summarized the strengths of case studies as addressing why and how an event occurs, providing a rich set of information on nonquantifiable relationships that exist among variables included in a study, and exploring topics unhindered by constraining theory. Of course, there are challenges to the use of case studies. For example, it is difficult to generalize findings from case studies to a larger setting, and the rigor of the researcher can be challenged on how he or she organized and analyzed the narrative form of the information.

4. Peer reviews. Peer review is an evaluation method where an independent panel of technical experts judges R\&D results. The evaluation is based on the experts' assessment of the quality of the research. Peer review is used by many federal agencies in project funding decisions, and it is gaining support for use in evaluating R\&D results. Criticisms levied against this technique include that it promotes "conservatism" and elitism among researchers (Bozeman, 1993, page 81).

5. Retrospective analyses. Retrospective analyses are long-term evaluations of federal R\&D benefits. They allow a systematic linkage between funding and outcomes with special 
attention on spillovers and spin-offs. They are similar to case studies in that they trace historical events. As such, they can incorporate the temporal dimension mentioned elsewhere in this report. As with case studies, retrospective analyses can be expensive. Moreover, such analyses cannot assist in assessing short-term outcomes (NAS, 1999).

6. Benchmarking. Benchmarking has become an often-used tool over the last several years for evaluating performance from a public administration perspective. Appropriate indicators are compiled to judge a program (state, local, federal, or international) against its closest competitors. Hence, in this context, indicators would assess whether the U.S. R\&D is cutting edge. The challenge in benchmarking for researchers to find comparable indicators and similar data-collection methods. Moreover, its use to date generally has been on programs outside the R\&D field.

Each of these methods has strengths and weaknesses, as summarized in Table 2.1. Regardless of which method or combination of methods a study uses to evaluate R\&D, the methodology must fit with the objectives. As Langbein (1980) noted, "most often, the controversy surrounding evaluative findings is methodological," e.g., matching the methodology with the objectives. Of course, multiple methods can be selected depending on the objectives. 
Table 2.1. Evaluation Methods Commonly Used

\begin{tabular}{|c|c|c|}
\hline Method & Strength & Weakness \\
\hline Economics & $\begin{array}{l}\text { Quantitative; shows monetary } \\
\text { benefits of research. }\end{array}$ & $\begin{array}{l}\text { Has not traditionally measured social } \\
\text { benefits; productivity lag makes this } \\
\text { difficult to measure; may not be } \\
\text { directly traceable to inputs. }\end{array}$ \\
\hline Bibliometrics & $\begin{array}{l}\text { Quantitative; patents can be reliable } \\
\text { indicator of nation's technological } \\
\text { strength in product development. }\end{array}$ & $\begin{array}{l}\text { Does not necessarily capture quality; } \\
\text { difficult to compare across disciplines. }\end{array}$ \\
\hline $\begin{array}{l}\text { Peer review or } \\
\text { subjective } \\
\text { assessments }\end{array}$ & $\begin{array}{l}\text { Well-understood by academics; can } \\
\text { provide rigorous evaluation of } \\
\text { research; procedure generally already } \\
\text { established in federal agencies. }\end{array}$ & $\begin{array}{l}\text { Dependent on quality of peer review } \\
\text { panel; subjective bias may occur; may } \\
\text { be expensive; is considered elitist; } \\
\text { conflicts of interest among researchers } \\
\text { may occur. }\end{array}$ \\
\hline Case studies & $\begin{array}{l}\text { Provide extensive qualitative and in } \\
\text { some situations quantitative in-depth } \\
\text { insights into project; generally focus } \\
\text { on processes. }\end{array}$ & $\begin{array}{l}\text { Difficult to generalize to broader } \\
\text { program area; cannot compare across } \\
\text { programs. }\end{array}$ \\
\hline $\begin{array}{l}\text { Retrospective } \\
\text { analyses }\end{array}$ & $\begin{array}{l}\text { Useful for identifying linkages } \\
\text { between federal expenditure and } \\
\text { long-term benefits. }\end{array}$ & $\begin{array}{l}\text { Cannot be used as short-term } \\
\text { evaluation tool. }\end{array}$ \\
\hline Benchmarking & $\begin{array}{l}\text { Comparison across programs and } \\
\text { countries. }\end{array}$ & $\begin{array}{l}\text { Difficult to find comparable } \\
\text { measurements and data collection } \\
\text { efforts. }\end{array}$ \\
\hline
\end{tabular}

Source: Compiled from NAS (1999); Geisler (1995); U.S. GAO (1997), Link and Scott (1998); Scherer (1965); Griliches (1998); Hyde, Newman and Seldon (1992); Chapman (1999); Fitzsimmons (2001); Rossi and Freeman (1985); Fischer (1995); Ammons (1995); Brown (1998); Bozeman and Melkers (1993).

Application of these measures can be conducted through statistical applications such as interrupted time series comparison group, pretest-posttest comparison group, or singleinterrupted time series (see Brown et al., 1994; Langbein, 1980; Babbie, 1998; Posavac and Carey, 1985). The method or indicator ultimately chosen should be valid, reliable, understandable, timely, comprehensive, sensitive to data collection and availability, and focus on controllable facets of performance (Ammons, 1995; Rossi and Freeman, 1985; Fischer, 1995). The technique should carefully delineate whether the researcher is evaluating input, process, output, short-run outcomes, and long-term outcomes. 


\subsection{METHODS USED FOR ALM PROGRAM EVALUATION}

Guided by the above review and our objectives, we chose three approaches to evaluate the benefits attributable to ALM projects: qualitative assessment, National Research Council (NRC) indicators, and economic analyses, including calculating a benefit-cost ratio incorporating energy, environmental, and security benefits and monetizing cost savings to industry accruing from access to federal R\&D funds. This combination addresses important aspects of the benefits of R\&D projects and supports recent recommendations to use multiple evaluation criteria (MacRae and Whittington, 1997; Langbein, 1980; Fischer, 1995). The qualitative assessment addresses immediate results at the project level and is conducted through a case studies approach mentioned above. The NRC indicators address standard measures associated with the evaluation of research projects and matches the peer review, benchmarking, and bibliometrics approaches discussed above. The benefit-cost analysis addresses long-term benefits associated with commercializing new technologies and matches the remaining economic and retrospective analyses approaches discussed above. ${ }^{5}$ Since ALM projects encompass both the creation of new knowledge and the commercialization of new technologies, both the indicator and economic approaches are appropriate for meeting the evaluation objectives. Each approach is outlined below.

\subsubsection{Qualitative Assessment}

This approach focuses on the subjective judgments of project participants concerning the benefits attributable to the projects. Were the project objectives met? Was new knowledge gained? Were technologies improved? What is the potential for commercialization of the new and/or improved technologies? Was the project a worthwhile investment of time and money? Did the project result in improved professional collaborations? Would the project have been undertaken by the private sector without federal assistance? These and other questions elicit the qualitative and somewhat intangible benefits of the R\&D projects and are short-term outputs.

Qualitative assessments most closely match the case studies approach from a methodological perspective. The case study approach has been used to evaluate U.S. Department of Defense research since the 1960s (see Kingsley, 1993). However, qualitative assessments are not common in R\&D evaluation among other federal programs. We included this as an evaluation method, however, because success of a project may hinge on those issues that can only be measured through a qualitative approach. The qualitative assessment supports the notion of using multiple methods for evaluations and provides an assessment on the collaborative efforts that might evolve among the Big 3 automakers, their suppliers, and national laboratories assumed

${ }^{5}$ We recognize that retrospective analyses can also occur several years after completion of an R\&D effort. 
when these ALM projects were funded. Most important, the qualitative approach meets our objective to measure short-run outputs.

Qualitative assessment requires that key participants (e.g., project managers) be interviewed, typically over the phone but in face-to-face settings if convenient. Also, project documents should be reviewed. These include progress reports, draft and final project reports, conference presentations, and conference and journal papers. The success of the approach depends on the willingness of key participants to be interviewed.

\subsubsection{National Research Council Indicators}

Our second approach stems from a report prepared by the National Academy of Sciences' National Research Council (NRC) on frameworks for evaluation of federal R\&D programs. The report was requested after GPRA passage. The NRC Committee on Science, Engineering, and Public Policy (COSEPUP) examined efforts to evaluate both basic and applied federal R\&D projects. COSEPUP recognized that there are "meaningful measures of quality, relevance, and leadership that are good predictors of usefulness" of R\&D results (NAS, 1999, page 2).

COSEPUP noted that progress toward "specified practical outcomes" can be measured on applied and basic research, such as those R\&D projects funded by ALM (NAS, 1999, page 5).

Three indicators were adopted from the COSEPUP work:

- the number of publications (including theses and/or dissertations) and presentations coming out of the research projects,

- the role of review panels in guiding and assessing the projects, and

- the participants' identification of appropriate indicators for measuring leadership in the international field, as well as an assessment of whether the United States is leading in R\&D on specific technology areas.

Fitzsimmons (2001) documented publications, presentations, and patents in a review of PNGV's Cast Light Metals and Rapid Tooling projects. Link (1995) used publications and presentations in his evaluation of the printed wiring board joint venture and short-wave sources for optical recording projects, a joint venture funded under the Advanced Technology Program at the National Institute of Standards and Technology, U.S. Department of Commerce. The U.S. Army Research Laboratory uses a number of refereed journal articles/proceedings, technical reports, and test reports in its evaluations (Brown, 1996). ${ }^{6}$ Geisler used publications and patents in his analysis of two national laboratories (Geisler, 1995). Thus, there is ample precedent for using a bibliometric indicator to evaluate ALM R\&D projects. As mentioned above, review panels are a standard means of assessing the quality of $R \& D$.

${ }^{6}$ These evolved from a case study in response to GPRA. 
The final indicator is specially designed for projects that also have the potential to improve U.S. competitiveness in a particular field. Information for these indicators is straightforward, collected from interviews with project participants and review of project materials. These measures assess short- and long-run benefits of an R\&D project. The bibliometric (e.g., publications) aspects can be considered as short-run (when the project is completed) and/or longrun (as when citations to articles indicate long-term contributions to new technology development, for example). The role of review panels most closely matches the peer review aspects set out in Table 2.1. Finally, identification of an indicator leads to benchmarking. Hence, choice of the NRC indicators incorporates bibliometrics, peer review, and benchmarking.

\subsubsection{Economic Analyses}

\subsubsection{Benefit-cost Analysis}

We chose two economic analyses as our third evaluation method; first, benefit-cost analysis. Benefit-cost analysis is an accepted tool in developing policy alternatives and for conducting program evaluations (Fischer, 1995). It allows for easy comparison of the benefits that would be achieved under a program versus the costs of that achievement. It is transparent in that benefits and costs can be clearly identified. Hence, it is a clearly understood tool. It is also frequently used as a program evaluation method where it is important to consider preliminary long-run benefits.

Application of benefit-cost methods to evaluate R\&D are numerous. The National Institute of Standards and Technology (NIST) has used present value of net benefits, present value of net savings, benefit-to-cost ratio, savings-to-investment ratio, and adjusted internal rate of return as economic measures in its analyses of: cybernetic building systems in office buildings; new standards for residential energy conservation; improved asphalt shingle for sloped roofing; and construction systems integration and automation technologies in industrial facilities (Chapman, 1999; Chapman and Fuller, 1996; Chapman, 2000). Social rates of return on public agricultural R\&D have been demonstrated for years (Alston, Norton and Pardey, 1995; Alston and Beach, 1996). Hamilton and Sunding (1998) used a form of economic analysis (production functions under imperfect competition) on public investments in agriculture. Martin, Gallaher and O'Connor (2000) calculated benefit-cost ratio, social rate of return, and net present value in an evaluation of NIST's standard reference materials for sulfur in fossil fuels. Marx, Scott and Fry (2000) calculated benefit-to-cost ratio and net benefits for NIST's investments in primary calibration services. Benefit-cost analysis has been used for evaluation of public R\&D investment in forestry (Hyde, Newman and Seldon, 1992). The Cockpit Automation Technology (CAT) program of the U.S. Air Force Armstrong Laboratory, U.S. Department of Defense, was reviewed within a benefit-cost framework (Rouse, Boff and Thomas, 1997). Papadakis and Link (1997) used cost-benefit in measuring the impacts of new business starts-ups on plasma spray technology and in measuring new or improved products/processes with polycrystalline diamond compact drill bit knowledge from Sandia National Laboratories. Link, Teece and Finan (1996) calculated a benefit-cost ratio in their evaluation of SEMATECH. Link and Scott (1998) 
estimated internal rate of return, implied rate of return, and ratio of benefits-to-costs for eight programs financed through the Advanced Technology Program, U.S. Department of Commerce.

It is assumed here that the primary benefit of the projects is to bring new technologies to the automotive market. Commercialization of the technologies, in turn, produces measurable secondary benefits with respect to reductions in energy use and emissions of air pollutants (which are explained more in Section 3). It is assumed that federal support for these projects will cause a net economic gain captured by comparing the introduction for a new technology resulting from DOE research with the next best alternative available, when the new technology was introduced or that would have been available absent DOE funding. Our methodology attributes energy, environmental, and security benefits to the project. ${ }^{7}$ This requires a baseline characterization of future energy markets without the government research, and an estimation of how baseline markets will react to the new or accelerated technology, including its market penetration.

Costs considered include federal and private sector expenditures on the projects. Costs of implementing the technologies, which may include equipment costs, training costs, marketing costs, etc., are difficult to include. These costs were not available from the companies, as these costs are business confidential. It is assumed that industry demands at least two-year payback periods on all such investments (DOE, 2002), so we ignore the first two years of the benefits for each of the technologies, arguing that these first two years' savings are needed to recoup the lifecycle capital costs of adopting the new technology.

We use two components to monetize benefits and costs, calculating a benefit-cost ratio and capturing person-year and cost savings by industry. Each is discussed below.

\section{Calculating a Benefit-Cost Ratio}

\section{Market Penetration}

The first effort to monetize benefits and costs pertains to benefits from the market penetration of new vehicles built with lightweight materials related to the projects under consideration. This component of the method requires market penetration forecasts, both with and without the commercialization of new technologies, of the number of vehicle components and/or parts that will be produced by the new technologies, and how many vehicles will be sold each year with these new, lightweight components. Also required is the identification of benefits attributable to each new vehicle (e.g., energy savings, environmental emission reductions, and security benefits) compared to today's vehicles, the magnitude of the benefits, and the monetized and discounted values of these benefits. These are challenging tasks that rely on informed judgements (e.g., from key participants' knowledge of market forecasting), engineering studies (e.g., for energy savings), and economic analyses (e.g., to value reductions in $\mathrm{CO}_{2}$ emissions).

${ }^{7}$ Obviously there is a public health benefit from a reduction in environmental emissions, although that is not a primary program responsibility of DOE. 
Fortunately, the literature contains most of the engineering studies and economic analyses needed for components of the benefit-cost analysis of ALM projects.

\section{Benefit-cost Ratios}

The market penetration benefits produce monetary benefit estimates, including energy, environmental, and oil security for each project. Then, the benefits are divided by the project costs to calculate benefit-cost ratios. As discussed earlier, the benefits for a project are defined as those attributed to the increased market penetration made possible by federal support, compared to that which would have been available absent DOE funding. Projects are deemed acceptable if the ratios are greater than or equal to 1.0. Projects typically need much higher ratios to be deemed successful.

\subsubsection{Person-Year and Cost-Savings Analysis}

The second monetary component in our analysis pertains to savings accrued, on average, to the firms participating in the R\&D project. Here, we consider how many person-years of research effort participation has saved the company (to achieve an equal knowledge level), and at what average cost. Marx, Scott and Fry (2000) and Link and Scott (1998) have considered these cost savings in their evaluations of NIST's R\&D efforts in primary calibration services and the Advanced Technology Program of the U.S. Department of Commerce, respectively.

\subsection{NATIONAL ACADEMY OF SCIENCES FRAMEWORK FOR DOE BENEFITS ASSESSMENTS}

Frameworks on evaluating DOE benefits in the R\&D field are evolving. Two reports issued since our first analysis should be mentioned here. In DOE's fiscal year 2000 budget, the U.S. House Appropriations Subcommittee directed an evaluation of the benefits from DOE R\&D programs conducted since 1978 (NAS, 2001a). Two programs-energy efficiency and fossil energy-were reviewed by the National Academy of Sciences' (NAS) Board on Energy and Environmental Systems. The NAS evaluation framework responded to the congressional mandate to evaluate whether "benefits . . . have accrued to the nation from the R\&D conducted since 1978 in DOE's energy efficiency and fossil energy programs" (NAS, 2001a, p. 1). Specifically the evaluation conducted by NAS asked "whether the benefits of the program have justified the considerable expenditure of public funds since DOE's formation in 1977," taking a comprehensive look at the "actual outcomes of DOE's research over two decades" (NAS, 2001a, p. 2).

To answer that evaluation question, the NAS framework attempts to systematically capture benefits that have occurred, paying particular attention to the reality that R\&D occurs within a dynamic system of marketplace, technological, and societal changes. The evaluation framework developed by NAS differentiates benefits; that is, the framework acknowledges that benefits such as knowledge accrue even though a technology may not be introduced commercially. 
NAS developed an evaluation matrix that captures three classes of benefits: economic, environmental, and security. Economic net benefits are defined as changes in market value of goods and services produced in U.S. economy under normal conditions. Economic benefits are intended to measure net economic gain captured by comparing the introduction of a new technology resulting from DOE research with the next best alternative available, when the new technology was introduced or that would have been available absent DOE funding.

Environmental net benefits are based on changes in quality of environment. Environmental benefits occur only if there is a net improvement in environmental quality from what would have been observed without the DOE R\&D program.

Security benefits are based on changes in the "probability or severity of abnormal energy-related events that would adversely affect the U.S. economy, public health and safety, or the environment" (NAS, 2001a, p. 3). This includes economic losses that might result from energy disruptions. Although traditionally thought of as unstable oil markets, there is increased concern at this point on security of energy-supply infrastructure (Lee et al., 2002).

To capture uncertainty about commercialization of technology developed under DOE R\&D funding, NAS considered three categories of benefits and costs: realized, options, and knowledge (see Table 2.2). Realized benefits and costs are those where the technology is virtually certain to enter the marketplace, while options benefits might accrue if the technology is introduced commercially. Knowledge benefits occur through the R\&D process even though a new technology may not be introduced and hence seeks to capture scientific knowledge developed through the R\&D process.

Table 2.2. NAS Matrix for Assessing Benefits and Costs

\begin{tabular}{l|c|c|c}
\hline & $\begin{array}{c}\text { Realized Benefits and } \\
\text { Costs }\end{array}$ & $\begin{array}{c}\text { Options Benefits and } \\
\text { Costs }\end{array}$ & $\begin{array}{c}\text { Knowledge Benefits } \\
\text { and Costs }\end{array}$ \\
\hline $\begin{array}{l}\text { Economic benefits } \\
\text { and costs }\end{array}$ & & & \\
\cline { 2 - 4 } $\begin{array}{l}\text { Environmental } \\
\text { benefits and costs }\end{array}$ & & & \\
\cline { 2 - 4 } $\begin{array}{l}\text { Security benefits and } \\
\text { costs }\end{array}$ & & & \\
\hline
\end{tabular}

Source: NAS, 2001a, page 3.

NAS recognizes that technology development occurs under two fundamental sources of uncertainty-technological uncertainty and uncertainty about economic and policy conditions. The NAS derivative matrix is shown in Table 2.3. The framework is both qualitative (e.g., 
knowledge benefits) and quantitative (realized benefits). NAS applied this evaluation framework through 22 case studies, including an examination of the PNGV program (see NAS, 2001a, pages 32-35 and 145-151). NAS monetized realized benefits only. It did, however, list qualitatively realized benefits, options benefits, and knowledge benefits and costs for each of the 22 case studies.

Table 2.3 NAS Derivation of Columns for the Benefits Matrix

\begin{tabular}{l|l|l|l}
\hline Economic/Policy Conditions & \multicolumn{1}{|c|}{$\begin{array}{c}\text { Technology } \\
\text { Developed }\end{array}$} & $\begin{array}{c}\text { Technology } \\
\text { Development in } \\
\text { Progress }\end{array}$ & $\begin{array}{c}\text { Technology } \\
\text { Development Failed }\end{array}$ \\
\hline $\begin{array}{l}\text { Will be favorable for } \\
\text { commercialization }\end{array}$ & Realized benefits & Knowledge benefits & Knowledge benefits \\
\hline $\begin{array}{l}\text { Might become favorable for } \\
\text { commercialization }\end{array}$ & Options benefits & Knowledge benefits & Knowledge benefits \\
\hline $\begin{array}{l}\text { Will not become favorable for } \\
\text { commercialization }\end{array}$ & Knowledge benefits & Knowledge benefits & Knowledge benefits \\
\hline
\end{tabular}

Source: NAS, 2001a, page 3.

In early 2002, a conference was held on "Estimating the Benefits of Government-sponsored Energy R\&D." In preparation for that meeting, Lee et al. (2002) suggested a modification of the NAS framework. The NAS charge was to assess retrospective benefits. However, Lee et al. noted that GPRA requires DOE to track performance from pre-programming planning through post-program evaluation. To capture the GPRA aspects of performance measurement, Lee et al. suggested that realized benefits in the NAS framework (see Table 2.2) be divided into realized retrospective and expected prospective benefits. This allows for tracking benefits over time. Lee et al. defined expected prospective benefits as those expected from

future deployment of a technology developed as a result of R\&D. . . . Estimation of expected prospective benefits requires a baseline characterization of future energy markets without the government research, and an estimation of how baseline markets will react to the new or accelerated technology, including its expected market penetration (Lee et al., 2002, page VIII).

Lee et al. defined option benefits from a prospective method as "an option value to $R \& D$ on technologies that are not being developed primarily to enter the market under the most likely conditions, but that would provide economically viable solutions under alternative plausible conditions" (Lee et al., 2002, page X). In a retrospective sense, option benefits would include "technologies that are already developed, but that are unlikely to be commercialized under current or anticipated market conditions" (Lee et al., 2002, page X). See Table 2.4. 
Table 2.4. Lee et al. Modification of NAS Framework

\begin{tabular}{l|l|l|l|l}
\hline & $\begin{array}{c}\text { Realized } \\
\text { Retrospective }\end{array}$ & $\begin{array}{c}\text { Expected } \\
\text { Prospective }\end{array}$ & Option & Knowledge \\
\hline Economic & & & & \\
\hline Environmental & & & & \\
\hline Security & & & & \\
\hline
\end{tabular}

Source: Lee et al., 2002, page vii.

It is unclear which evaluation framework DOE will ultimately adopt to assess the benefits of its R\&D efforts, be it the original NAS framework or the Lee et al. revision or even the framework presented in this report. However, it is important at this point to review how the framework used in our evaluation compares with that proposed by NAS (Das, Peretz and Tonn, 2001). We capture realized, options, and knowledge benefits though we do not use those labels in measuring the short-run outputs and long-term outcomes of the ALM R\&D projects.

For a more explicit comparison of the NAS framework and ours, we set the indicators we use into the NAS benefits matrix (refer to Table 2.2) to form Table 2.5. It should be pointed out that for the PNGV program, NAS did not quantify benefits and costs in its case study. For reference, we have included the NAS list of benefits and costs for PNGV in Appendix B of this report. 


\section{Table 2.5. Comparison of NAS Framework and Das, Peretz and Tonn Framework}

\begin{tabular}{|c|c|c|c|}
\hline & $\begin{array}{l}\text { Realized Benefits and } \\
\text { Costs }\end{array}$ & $\begin{array}{c}\text { Options Benefits and } \\
\text { Costs }\end{array}$ & $\begin{array}{c}\text { Knowledge } \\
\text { Benefits and } \\
\text { Costs } \\
\end{array}$ \\
\hline $\begin{array}{l}\text { Economic benefits and } \\
\text { costs }\end{array}$ & $\begin{array}{l}\text { 1. Energy savings. } \\
\text { 2. Reduced costs to } \\
\text { consumers/manufac- } \\
\text { turers of materials. } \\
\text { 3. Person-year and cost } \\
\text { savings to industry. }\end{array}$ & $\begin{array}{l}\text { 1. Energy savings. } \\
\text { 2. Reduced costs to } \\
\text { consumers/manufac- } \\
\text { turers of materials. } \\
\text { 3. Person-year and cost } \\
\text { savings to industry. }\end{array}$ & $\begin{array}{l}\text { 1. Was } \\
\text { collaboration } \\
\text { enhanced? } \\
\text { 2. Was new } \\
\text { information } \\
\text { yielded? } \\
\text { 3. Were technical } \\
\text { objectives met? } \\
\text { 4. Would company } \\
\text { have participated } \\
\text { without DOE } \\
\text { funding? } \\
\text { 5. Number of } \\
\text { publications? } \\
6 . \text { Is U.S. leading } \\
\text { in research in this } \\
\text { field? } \\
\text { 7. Will research } \\
\text { improve U.S. } \\
\text { international } \\
\text { competitiveness? } \\
\text { 8. Were outside } \\
\text { review panels } \\
\text { used? }\end{array}$ \\
\hline $\begin{array}{l}\text { Environmental benefits } \\
\text { and costs }\end{array}$ & $\begin{array}{l}\text { Benefit-cost analysis } \\
\text { focusing on energy, } \\
\mathrm{CO}_{2}, \mathrm{CO}, \mathrm{PM}_{10}, \mathrm{NO}_{\mathrm{x}} \\
\mathrm{SO}_{\mathrm{x}} \text { emissions. }\end{array}$ & $\begin{array}{l}\text { Benefit-cost } \\
\text { calculations for energy, } \\
\mathrm{CO}_{2}, \mathrm{CO}, \mathrm{PM}_{10}, \mathrm{NO}_{\mathrm{x}}, \\
\mathrm{SO}_{\mathrm{x}} \text { emissions. }\end{array}$ & $\begin{array}{l}\text { Life-cycle analysis } \\
\text { on environmental } \\
\text { impacts of new } \\
\text { technology. }\end{array}$ \\
\hline $\begin{array}{l}\text { Security benefits and } \\
\text { costs }\end{array}$ & Petroleum disruption. & Petroleum disruption. & $\begin{array}{l}\text { Quantification of } \\
\text { reduced demand } \\
\text { for oil. }\end{array}$ \\
\hline
\end{tabular}

\subsection{SUMMARY OF METHODS}

Table 2.6 summarizes the four methods used in this research to assess the benefits attributable to ALM projects. The set of methods allows the assessment of qualitative factors and the development of quantitative benefit measures. All the methods have precedent in the literature as pointed out above. Together, the methods can provide comprehensive insights into the short- and 
long-run benefits of the R\&D projects. Most important, they met our program evaluation objectives.

Finally, it should be pointed out that this program evaluation does not constitute a full-fledged GPRA assessment although we use terms defined in GPRA. To accomplish the complete intent of GPRA, every ALM program currently funded as well as those completed would need to be incorporated into this analysis.

Table 2.6. Evaluation Methods Used in this Research

Method

Qualitative assessment

National Research Council indicators

Economic analysis - benefitcost and market penetration

Economic analysis - personyear and cost savings
Description

Assessment of participants' subjective views about the benefits attributable to the projects.

Quantitative measurement of publications, qualitative assessment of role of review panels, qualitative identification of benchmarks to gauge international competitiveness.

Quantitative measurement of benefits associated with the accelerated market penetration of new, lightweight vehicles whose production benefited from the research projects; measures include energy savings, air pollution emission reductions, and security benefits.

Quantitative measurement of person-year savings by industry through access to federal R\&D funds, quantitative measurement of cost savings accrued by industry through access to federal R\&D funds. 


\section{AUTOMOTIVE LIGHTWEIGHTING MATERIALS PROJECTS}

The Automotive Lightweighting Materials (ALM) Program, a major component of the Office of Advanced Automotive Technologies (OAAT) in the U.S. Department of Energy's (DOE's) Office of Transportation Technologies (OTT), focuses on the development and validation of advanced lightweight materials technologies to significantly reduce automotive vehicle body and chassis weight without compromising other attributes such as safety, performance, recyclability, and cost. The ALM program funds numerous projects each year in support of its five areas of research, i.e., cost reduction, manufacturability, design data and test methodologies, joining, and recycling and repair. The single greatest barrier to use of lightweight materials is their high cost; therefore, priority is given to activities aimed at reducing costs through development of new materials, forming technologies, and manufacturing processes. In this report, three recently completed R\&D projects focusing on different areas of research were selected for evaluation. These projects include: design and product optimization for cast light metals; durability of lightweight composite structures; and rapid tooling for functional prototyping of metal mold processes. There are similarities among the three selected projects. The first and last projects are related to casting of aluminum; the second one focuses on the enabling technology for glass-fiber reinforced polymer composites. The first and second projects are similar with respect to the area of research, i.e., design data and test methodologies. The following paragraphs discuss each of these projects in detail.

\subsection{DESIGN AND PRODUCT OPTIMIZATION FOR CAST LIGHT METALS}

The objective of this project was to develop information and technology for the U.S. automotive industry that will optimize design and improve product capabilities for lightweight, highstrength, cast structural aluminum components of chassis and interiors (AFS, 2001). A lack of comprehensive material design guidelines, limited qualified-supplier base, casting inconsistencies, and higher cast component cost have been some of the major barriers for the high-volume use of cast light metal alloys for automotive structural components. This project was designed to define the strategy for reducing the weight of structural/chassis components (which are primarily aluminum castings) by 50\%. This 5-year project, initiated in 1995, consisted of a fairly large team of 32 companies, including several personnel from the Big 3 automotive companies, national laboratories, independent companies from the casting supply base, two trade associations (the Aluminum Association and the American Foundry Society), academia, and independent testing and research laboratories. The project accomplished several major activities, including development of a comprehensive cast light metal property database, an automotive application design guide, computerized predictive models, process monitoring sensors, and quality assurance methods. An implementation of all of the project findings was also undertaken by optimizing the mule casting - a production-cast rear lower control arm resulting in a $20 \%$ weight savings and cost savings of $\$ 1.91 /$ part or $\$ 3.82 /$ vehicle. In addition, 
several cooperative research and development agreements (CRADAs) resulted in the development of commercial software for the porosity prediction for a permanent mold casting, final element simulations for the control arm with different initial levels of porosity, and radiographic analysis of validation mule castings to determine discontinuity types and grades at predicted high stress locations.

The materials property database includes historical literature data and comprehensive mechanical property data derived from samples excised from actual production aluminum chassis castings. This can also be used for comparing aluminum and magnesium by using an entirely different architecture. This database provides the capability to automobile casting industry designers and engineers to view the information and compare microstructure and mechanical properties of various processes of light metal cast components. The design guide developed for the cast light metal structural components that meet mass, durability, and cost targets incorporates learning from successful applications, property database information, and industry input. The development of computerized predictive models focused mainly on cast microstructure and subsequent mechanical properties throughout cast component sections based on an evaluation and development of numerical modeling techniques. Also developed were on-line process monitoring, feedback control, and nondestructive evaluation techniques and sensors to ensure cast component consistency and quality.

\subsection{DURABILITY OF LIGHTWEIGHT COMPOSITE STRUCTURES}

A lack of design guidelines to guarantee 15-year durability of automobile components impedes automotive application of structural composites today. This project, closely coordinated between Oak Ridge National Laboratory (ORNL) and the Automotive Composites Consortium (ACC) of United States Cooperative Automotive Research (USCAR), developed experimentally based, durability-driven design criteria to ensure the long-term (15-year) integrity of polymeric composite automotive structures. Validation of the applicability of the guidelines to representative structures under realistic loadings and environments was the secondary goal of this project. Durability issues included the potentially degrading effects of both cyclic and sustained loadings, exposure to automotive fluids, temperature extremes, and low-energy impacts (for example, from tool drops and roadway kickups) and how they affect structural strength, stiffness, and dimensional stability. The initial project focused on random glass fiber composites, which is being considered for the analysis here, and was completed after six years (in fiscal year 1999). The current focus is carbon-fiber composites having higher mass reduction potential.

A durability-based design criteria document was prepared for a chopped-glass fiber/urethane matrix composite that closely resembles the Programmable Powdered Preforming Process (P4) composite in the ACC's Focal Project II (one of the validation activities) pickup box. In addition to the design criteria, a damage-based predictive model was developed for creep deformation, 
including a theory for predicting time to rupture under time-dependent creep conditions for the chopped-fiber composite. This was based on a complete testing of a reference material followed by partial testing of a similar material, replicating on-road conditions, in laboratory specimens for verification of models and methods. Also developed under this R\&D effort were minimum test requirements and suggested test methods to be used by suppliers and testing organizations for establishing the durability properties and characteristics of candidate random glass-fiber composites for automotive structural composites. The results of this project have been instrumental in the commercial automotive structural application of glass-fiber reinforced polymer composites as observed in pickup boxes of 2001 Chevy Silverados by General Motors and the single-piece cargo box of the Ford Explorer Sport Trac.

\subsection{RAPID TOOLING FOR FUNCTIONAL PROTOTYPING OF METAL MOLD PROCESSES}

The lead time for bringing a cast component from concept and design into production is critical to increasing the castings' share of new automotive markets. The major contributors to lead time in cast components are tooling construction and process development. This 4-year project, completed in 1998, involved a partnership with the U.S. Department of Energy, the Big 3 automakers, and independent die casters, die builders, and other industry suppliers. The project's goal was to help bring automobiles to market faster with lower costs by speeding the development and production of prototype parts. The objective of this project was to reduce tooling time, originally some 48-52 weeks, to less than 12 weeks by means of rapid generation of die cast die inserts and development of generic holding blocks, suitable for use with large casting applications. The two technologies found to be suitable for and capable of producing dimensionally accurate tooling include: (i) rapid machining/manufacturing of tooling constructed from tool steel and (ii) investment cast tooling made from patterns created by the stereolithography (SLA) rapid prototyping process. The time reduction during the tooling construction was accomplished by the rapid machining/manufacturing associated with the use of prehardened tooling, time savings associated with the elimination of "benching" (i.e., hand polishing), elimination of machine setups associated with machining after final heat treatment and the strict requirement that no engineering changes be made once tooling construction had begun. This rapid machining/manufacturing process was proven through two case studies. A mid-size transmission case and a torque-converter housing were die cast within 16 and 7.5 weeks, respectively, after the release of the purchase order. The project achieved its objective of reducing tool-build time by $75 \%$ - more than $50 \%$ above the performance goal set by the metal casting industry.

The investment cast tooling made from the patterns created by the SLA process saved time in the pattern making by going directly from database to the pattern making and using plastics instead of wax. In addition, this process allows an extensive reduction in machining of the die after the last stage of the conventional die-making process. The generic holding block, used for holding a large number of dies, was designed to be compatible with a family of transmission components 
common to GM, Ford, and DaimlerChrysler. This also was run successfully for the production of mid-size transmission components. In the long term, the generic nature of this block eliminates a major time hurdle in the construction of tooling for functional prototypes. 


\section{RESULTS}

\subsection{QUALITATIVE ASSESSMENT}

This approach entails contacting key project participants for subjective assessments of the benefits of each project described in Section 3. The information gathering process is described immediately below. The results for each project are presented in Sections 4.1.2 through 4.1.4. A summary of the overall results of the qualitative assessment is presented in Section 4.1.5.

\subsubsection{Information Gathering}

For the assessment, we interviewed key participants in each research project following a standard set of prepared questions. Key participants are defined as project managers and their assistants. The project managers possess the detailed yet strategic knowledge about the projects and potential technology commercialization needed for the evaluation; project staff may not have strategic knowledge whereas the higher level managers probably are not aware of important project details. Additionally, if there is information relevant to the evaluation that a project manager does not know or possess, we expect the project manager will refer us to the proper person or resource. Focusing on project managers reduces the number of interviews needed. Since we are not using the interviews to generate hypotheses for statistical analyses, this approach allows us to capture the information needed for the qualitative assessment. Finally, interviewing those directly involved in the project design and implementation has been used in other R\&D assessments (see Rouse, Boff and Thomas, 1997).

We defer to the key participants on how they wish for us to gather the information needed for our analysis, e.g., telephone, telephone with the opportunity to review a set of questions prior to the interview, e-mail or U.S. postal service mailing of the questions to which participants would reply. In this evaluation, all participants indicated they preferred a mailed set of questions (either e-mail or U.S. postal service), and several indicated that they would not respond to a telephone interview. In an effort to reduce the time commitment required of the key participants, in two of the three case studies presented here we borrow from the research effort of Beth Fitzsimmons in her dissertation, "Knowledge Spillovers from Joint Government-Industry Supported Research: A Case-Study from the Automotive Industry" (2001). Specifically, we use her assessment of collaboration and numbers of publications and presentations.

To confirm key participants in the cast light metals project, we contacted the two lead investigators; they provided a mailing list of the 32 participants in that project. For the durability of composite structures, we reviewed DOE status reports and confirmed a contact list with the Oak Ridge National Laboratory (ORNL) principal investigator. Four representatives from the 
auto industry participated with ORNL in this effort. The principal investigator for ORNL served as the source of information for the laboratory work.

Contacting key participants in the rapid tooling process project was more challenging. Of the eight key participants identified initially through project reports, two of the four automotive representatives have left their employers. Of the two remaining, one preferred not to participate. Of the key participants from the national laboratories, one had been promoted shortly after the project began to a high-level management position and had little active involvement in the R\&D effort. Two others were no longer employed at the national laboratories. To complete a list of contacts for this evaluation, we spoke with the project's trade association manager involved in the R\&D effort. He provided a list of four industrial representatives that participated actively in the project and that were still employed in the auto industry or first tier supplier. The project administrator also agreed to provide an overview. Despite the difficulty in locating the original set of investigators, of the five key participants eventually identified, four completed our questions.

We sent each key participant in the three R\&D projects a set of questions. A follow-up message was sent to those not responding three weeks after initial contact. A third contact included another copy of the questions. In all instances, the interviewees were assured confidentiality. Thus, no responses in this report are attributed directly to any interviewee. Instead, the responses are phrased in more generic terms.

Our participation rates varied across projects. In the cast light metals project, we had a response rate of $56 \%$; durability of composite structures, $80 \%$; rapid tooling process, $80 \%$. It should be noted that in the durability of composite structures R\&D project, one key participant retired during our contact period and did not participate although he was sent a set of questions (hence the $80 \%$ participation rate). The number of contacts, completed questions, and response rates are set out in Table 4.1 .

Table 4.1. Response Rates for Analysis

\begin{tabular}{lccc}
\hline \multicolumn{1}{c}{ R\&D Project } & Number Contacted & Number Completed & Response Rate \\
\hline Cast light metals & 32 & 18 & $56 \%$ \\
\hline $\begin{array}{l}\text { Durability of composite } \\
\text { structures }\end{array}$ & 5 & 4 & $80 \%$ \\
\hline Rapid tooling process & 5 & 4 & $80 \%$ \\
\hline
\end{tabular}


We recognize that the sample size is small. This is simply based on the fact that there were small numbers of people involved with the projects. We did not interview people not directly involved with the projects. From our review of the literature, interviewing only those directly involved in the project is the recommended approach (e.g., see Rouse, Boff and Thomas 1997). It does not seem to be worth the cost to interview people who were unlikely to have anything of value to contribute to the evaluation of the projects.

Methodologically speaking, the small sample sizes is not an issue of concern. We approached the interviews from a case study perspective. We had no intention of using (and did not use) the interview data to statistically test any hypotheses or to generalize the interview results to other projects or programs. Thus, there were no methodological requirements for large sample sizes.

\subsubsection{Design and Product Optimization for Cast Light Metals}

The goal of this 5-year project sought to define a strategy for reducing weight of structural/chassis components (which are now primarily aluminum castings) by $50 \%$. According to the final report submitted to DOE, deliverables from this research effort include math-based models; new architecture for comparing aluminum and magnesium historical data; design guidelines for cast light metal structural components; temperature sensors for process monitoring; and quality assurance methodologies/equipments (American Foundry Society, 2001). As noted above, 32 companies were involved in the project. Staff effort committed by the industrial sector was significant, as in one year alone one firm responding to our questionnaire devoted 30 staff members at $30 \%$ effort.

Seventy-two percent of those responding indicated that the technical objectives of the project were met, and $89 \%$ indicated that the research and development project yielded new knowledge.

Several respondents (50\%) indicated that they would not have participated in R\&D on cast light metals without financial support from DOE. About $39 \%$ of the participants indicated that they would have participated. Of those that would have participated regardless of DOE funding, the financial effort varied. One respondent indicated $\$ 25,000$; the highest level of effort was between $\$ 500,000$ and $\$ 1$ million. Person-level commitment for the project, without DOE funding, ranged from one-quarter person-year for two companies, to three or four professors and three or four graduate students, to two firms with one person-year effort each.

Reasons given by those companies that would not have participated without DOE included: cost to achieve goals would not have been affordable, coordination of all key players would have been difficult, and proprietary issues. One respondent noted that without DOE financial support the project may not have been as comprehensive as it was. Another noted that it already had technology equal to what was proposed and hoped to push that technology. 
Because we did not wish to duplicate the research effort of Fitzsimmons, we rely on her results for collaboration enhancement among the participants. Fitzsimmons reported new subcontracts, partnerships, and informal alliances formed among suppliers, customers, and national laboratories (Fitzsimmons, 2001, see pages 85-86). One can conclude from this that collaboration was enhanced through this 5-year effort.

With regard to whether the participants will incorporate the results as they manufacture parts for light-duty vehicles, $40 \%$ said they would, $53 \%$ indicated they would not, and $7 \%$ responded that the question was not applicable to their company. For those that will not incorporate the results, the reasons varied. Some indicated they manufacture heavy-duty machines, rather than lightduty vehicles, and will use the results for that effort. For those non-auto specific industry respondents who supply different tools that go into the auto manufacturing process, respondents indicated that their business is customer-driven. Another respondent commented on higher costs.

To gauge the potential for spin-offs from the R\&D project, $20 \%$ said that the company used knowledge from this R\&D project to spin-off a new product line. Moreover, $36 \%$ indicated that they were aware of other industries that have benefited from this R\&D effort through various applications.

We included an open-ended question so firms could share comments about this R\&D project. As expected, some comments were positive, others negative; some sought more information, while others cited weaknesses in the R\&D project in general. Some firms noted the excellent management of the project and valuable technology developed, while others expressed that it was well-organized and met its objectives. One noted the significance of bringing together a diverse group of suppliers to work with the Big 3 automakers. Some respondents felt that universities and national laboratories are removed from manufacturing applications, but noted the Lawrence Livermore National Laboratory provided valuable research results. Others questioned resource allocations, felt there was no accountability, and observed few results. One firm would like more information on magnesium. Participants noted that the success of the project will ultimately depend on U.S. auto industry adoption, while another emphasized that the research should be distilled into practical application. One noted that this analysis should be repeated in 5 to 10 years in order to compare predictions with actual adoption. Such varied results are not unexpected in a project that had this many participants. The results also point out the realities of transitioning from an R\&D effort to manufacturing application. Nevertheless, the respondents expressed positive benefits emanating from this $R \& D$ effort.

\subsubsection{Durability of Lightweight Composite Structures}

The objective of this project was to develop experimentally based, durability-driven design criteria to ensure the long-term (defined as 15 years) integrity of polymeric composite automotive structures. Durability issues included potentially degrading effects of both cyclic 
and sustained loadings, exposure to automotive fluids, temperature extremes, and low-energy impacts (from, for example, tool drops and roadway kickups) and how they affect structural strength, stiffness, and dimensional stability. As such, the durability project should be considered a basic research project, rather than a technology development project. This project involved staff under the direction of Oak Ridge National Laboratory (ORNL) (in one year, 13 people at $40 \%$ effort) working with an oversight group of Big 3 representatives.

Accomplishments included:

1. Durability-based design criteria document for chopped-glass-fiber composite that closely resembles the P4 composite used in Focal Project II pickup box.

2. A damage-based prediction model for chopped-fiber composites.

3. Published report on durability test protocol.

Hence the output from this R\&D effort is knowledge- and documentation-based. This project is one of several tasks that supported one of the validation activities, called focal projects, (developed between 1995 and 1999) that demonstrate ALM program goals and reduce the lead time to bring new technology into the marketplace. These focal projects focus on specific classes of materials and nonproprietary components and are done jointly by DOE and ACC of USCAR. The goal of Focal Project II, in which the durability of lightweight composite structure was a component, was to develop and demonstrate rapid manufacturing technology, material performance data, and reliable assembly methods for producing large and complex composite automotive structures. This project demonstrated the feasibility of producing composite pickup truck boxes-at a rate of one every 4 minutes-that meet all performance criteria and weigh $25 \%$ less than and cost no more than a comparable steel structure.

All respondents agreed that the technical objectives were met, that new knowledge was yielded, and collaboration between the auto industry and ORNL was enhanced through the R\&D effort. Only one of the firms responding indicated that it would have pursued this R\&D effort without DOE funding, but the financial effort would have been small (less than \$75,000) and with less than one full-time person-year effort. One company representative felt that the undertaking was too large for his company. He replied that DOE had the expertise and equipment to accomplish the goals set out, while another company representative noted the expertise of ORNL to complete the task.

Because much of the project output is documentation, we assessed whether the auto industry is using the durability-based design criteria developed. One respondent indicated that his firm is using some of the criteria but noted that integration into design process is a challenge. Another participant said that his company is using the criteria, while a representative from the third automaker said that his company is using the criteria indirectly. With regard to the durability test protocol developed by ORNL, all three representatives from the auto industry indicated that the protocol is being used. 
Respondents cited cost, unknown long-term performance or confidence, manufacturing base, component cycle time, and acceptance by automotive release engineers as barriers to introducing composite structures in light-duty vehicles on a wide scale.

The three respondents from the auto industry indicated, in general-comment form, that this R\&D project was an extremely important effort that provided a significant amount of knowledge to the composite industry and positive benefits were associated with the R\&D effort. The ORNL project staff was complimented. One participant suggested that this was an outstanding example of how DOE, ORNL, and industry should work together. One noted that the benefits will occur over the long-term because the R\&D effort addressed issues that are important in longer range applications.

\subsubsection{Rapid Tooling for Functional Prototyping of Metal Mold Processes}

The objective of this 4-year R\&D effort was to develop the materials processing and design technologies required to reduce the die development time for metal mold processes from 12 to 3 months, using die casting of aluminum and magnesium parts in the example process. Two major areas were identified to reduce the die development time: (1) rapid generation of die cast die inserts; and (2) a generic holding block suitable for use with large casting applications. The Big 3 respondents to our questionnaire noted that for two years of the project, 6-8 staff members devoted between 35 and $65 \%$ of their full-time effort to this R\&D program.

All participants agreed that the objectives were met and that new knowledge was yielded from this R\&D effort (see results published in Die Cast Engineer, for example, Bralower, 1998). None of our respondents would have participated in R\&D on rapid tooling without financial support from DOE. Reasons for not participating include project cost. One respondent indicated that his company would not have dedicated resources without funding or had the motivation to proceed without the DOE effort. Other respondents felt that divisional support came through having access to leveraged funding.

With regard to collaboration enhancement, we once again relied on Fitzsimmons' research. She found in her study of this R\&D effort that interest in collaboration was a benefit of working on PNGV projects. She found that $66 \%$ of her respondents on the rapid tooling project indicated that PNGV was responsible for increased collaborations. There was greater collaboration with smaller companies, universities, and government entities. In addition, the initial collaboration has encouraged future collaborations (Fitzsimmons, 2001, see pages 96-101).

The results from this R\&D project have been incorporated by some companies for manufacturing parts for light-duty vehicles. GM is using the results for transmission cases and engine blocks. One respondent pointed out that GM has embraced this technology more quickly than the other two automakers. 
In response to our open-ended question on sharing information with DOE about this project, some respondents expressed complete satisfaction with the outcome of the project. One commented on the importance of appropriate staffing for R\&D projects. This respondent felt for this project that product development staffing may have been more important than staff with a materials background. Sentiments among interviewees indicated positive benefits accrued because of the project.

\subsubsection{Summary of Qualitative Assessment}

Table 4.2 summarizes the qualitative assessments for the three projects. Overall, the qualitative assessment is very positive for the three projects. All the technical objectives were met and all yielded new knowledge. In one case, the private sector participants indicated that they would not have participated in the R\&D effort without federal funding. In the second and third cases, some participants would have proceeded with R\&D but with considerably less funding than with DOE funding. In all cases, collaboration among the participants was enhanced. The rapid tooling process is being used by one of the Big 3 automakers, and all Big 3 automakers are using (to some degree) the design manuals developed under the durability of composite structures project. 
Table 4.2. Summary of Qualitative Assessments

\begin{tabular}{|c|c|c|c|c|c|}
\hline Project & $\begin{array}{c}\text { Met technical } \\
\text { objectives? }\end{array}$ & $\begin{array}{l}\text { Yielded new } \\
\text { knowledge? }\end{array}$ & $\begin{array}{c}\text { Will technology } \\
\text { be } \\
\text { incorporated? }\end{array}$ & $\begin{array}{c}\text { Would } \\
\text { company } \\
\text { have } \\
\text { participated } \\
\text { without } \\
\text { federal } \\
\text { funding? }\end{array}$ & $\begin{array}{c}\text { Was } \\
\text { collaboration } \\
\text { enhanced? }\end{array}$ \\
\hline $\begin{array}{l}\text { Cast light } \\
\text { metals }\end{array}$ & Yes & Yes & Mixed & $\begin{array}{c}\text { Mixed. For } \\
\text { those who } \\
\text { would have, } \\
\text { not with as } \\
\text { many } \\
\text { resources. }\end{array}$ & Yes* \\
\hline $\begin{array}{l}\text { Durability of } \\
\text { composite } \\
\text { structures }\end{array}$ & Yes & Yes & Yes & $\begin{array}{l}\text { Mixed. For } \\
\text { those who } \\
\text { would have, } \\
\text { not with as } \\
\text { many } \\
\text { resources. }\end{array}$ & Yes \\
\hline $\begin{array}{l}\text { Rapid tooling } \\
\text { process }\end{array}$ & Yes & Yes & Yes & No & Yes* \\
\hline
\end{tabular}

*Source: Fitzsimmons, 2001, see page 98-102.

\subsection{NATIONAL RESEARCH COUNCIL INDICATORS}

The National Research Council indicators used in our framework are: number of publications and presentations, outside review panels, international competitiveness, and an appropriate benchmark for gauging international competition. Number of publications for the cast light metal and rapid tooling projects are taken from Fitzsimmons (2001).

\subsubsection{Publications and Presentations}

The number of publications was extensive for these projects. For the cast light metals project, Fitzsimmons reported 44 publications in the first four years. Many of these were published by the national laboratories, universities, and motor vehicle companies. Fitzsimmons also reported 82 presentations made by the cast light metals team (Fitzsimmons, 2001). 
In the durability of composite structures project, seven technical manuals or guidance documents were produced, 14 conference proceedings, and 12 peer-reviewed journal articles. In addition, two theses were completed by graduate students.

For the rapid tooling project, eight articles were published. Dissemination through conference presentations served as an important outlet for the rapid tooling process projects findings as well, as Fitzsimmons reported from the rapid tooling effort (Fitzsimmons, 2001, see pages 88-90). Considering the extensive number of presentations and publications, these three R\&D projects have certainly increased knowledge benefits.

\subsubsection{Peer review}

None of the projects used an outside peer review team in the format envisioned by NRC (a finding identical to our previous analysis). However, respondents in the cast light metals project noted the steering committee's role in oversight, as well as the roles of product development engineers and material scientists. For the durability of composite structures project, there was close interaction between the national laboratory team members and the auto industry. The auto industry representatives served on semi-annual reviews. For the rapid tooling effort, a respondent noted the use of steering committees.

\subsubsection{International Competition and Appropriate Indicators}

With regard to the cast light metals project, the majority of respondents perceived that the United States is following or about even with other countries in research of product design on use of cast light metals in manufacturing parts for light-duty vehicles. Only 17\% of participants judged that the United States is leading in research. Fifty-nine percent felt that the United States is following, while 24\% viewed the United States as about even with other countries. Fifty percent of our respondents listed Germany specifically as a country leading in research, while $7 \%$ listed Europe; another 14\% cited Germany and Japan together, and finally, $7 \%$ grouped the United States with Europe.

We found similar results on how respondents compared the United States internationally on commercial use of product design for use of cast light metals in manufacturing parts for lightduty vehicles. Here only 19\% felt that the United States is leading, while 50\% said the United States is following, 31\% viewed the United States as about even with other countries. Again, Germany was identified individually as the country leading in commercial use, with (1) Europe and (2) Germany and Japan together receiving 20\% on countries leading.

On the durability of composite structures $R \& D$, all respondents agreed that the United States is leading other countries in research on durability of lightweight composite structures for use in manufacturing parts for light-duty vehicles. One participant commented that the United States is 
the country that has focused on large projects. Two of our respondents noted that the United States is leading other countries in commercial use of lightweight composite structures for lightduty vehicles; a third respondent felt the United States is about even with other countries.

For the rapid tooling process effort, there was about an even split among respondents on whether the United States is leading or about even with other countries in research on rapid tooling processes used in product design for manufacturing parts for light-duty vehicles. Two indicated that the United States is leading, while two others felt the United States is about even. Responses to our query on whether the United States is leading or about even with other countries in commercial use of rapid tooling processes in product design for manufacturing parts for lightduty vehicles were similar to the responses on research. Fifty percent said the United States was leading, while the other 50\% indicated that the United States was about even with other countries.

We included an open-ended question on what measure is appropriate for gauging U.S. competitiveness in this area. The overwhelming majority of the answers in the cast light metals R\&D effort could be labeled as "use of light weight materials in automobiles" as a measure. The respondents from the durability of composite structures questionnaire suggested these measures for gauging U.S. competitiveness: number of large primary structural components in vehicle production; number of vehicles produced with composite structures; variety of applications of composite structures; and amount of composite structure materials used. The rapid tooling participants suggested (1) shortening the product introduction cycle (defined as concept to release to the consumer) or vehicle development processes (similar to the product introduction cycle). Another suggested, though a specific measure was not offered, that competitive benchmarking is needed to gauge U.S. competitiveness.

We included a series of statements on whether the R\&D project has or will help an individual company and the U.S. automotive sector in general to incorporate the results of the R\&D projects into manufacture of light-duty vehicles more rapidly than would have occurred without the R\&D effort (our research here was gleaned from Link, 1997). We also asked whether the R\&D effort would increase the participants' national and international competitiveness. We used a 5-point scale (strongly agree to strongly disagree) for the responses.

The strongly agree or agree responses to the importance of the R\&D effort for each project are provided in Table 4.3. The results indicate that the $R \& D$ effort will in virtually every case help the firms incorporate the results into the manufacture of light-duty vehicles and increase the competitiveness of the individual company and the U.S. automotive sector in general in the domestic and international market for light-duty vehicles than would have occurred without involvement in the R\&D effort. This is particularly the case for those who responded to this set of questions for the rapid tooling project $\mathrm{R} \& \mathrm{D}$ effort. 
Table 4.3. Responses to Importance of R\&D Project to

Competitiveness of Firms Involved in R\&D Project (Strongly Agree or Agree Responses)

\begin{tabular}{|c|c|c|c|}
\hline & $\begin{array}{l}\text { Cast light } \\
\text { metals }\end{array}$ & $\begin{array}{c}\text { Durability } \\
\text { of } \\
\text { composite } \\
\text { structures }\end{array}$ & $\begin{array}{c}\text { Rapid } \\
\text { tooling } \\
\text { process }\end{array}$ \\
\hline $\begin{array}{l}\text { This project will help my company incorporate [project results] into the manufacture of our light-duty vehicles more rapidly than } \\
\text { would have occurred without involvement in this research and development effort. }\end{array}$ & 50.1 & 100 & 100 \\
\hline $\begin{array}{l}\text { This project has helped my company incorporate [project results] into the manufacture of our light-duty vehicles more rapidly than } \\
\text { would have occurred without involvement in the research and development effort. }\end{array}$ & 46.6 & 66.7 & 100 \\
\hline $\begin{array}{l}\text { This project will help the U.S. automotive sector in general to incorporate [project results] into the manufacture of light-duty } \\
\text { vehicles more rapidly than would have occurred without the research and development effort. }\end{array}$ & 82.3 & 100 & 100 \\
\hline $\begin{array}{l}\text { This project has helped the U.S. automotive sector in general incorporate [project results] into manufacture of light-duty vehicles } \\
\text { more rapidly than would have occurred without the research and development effort. }\end{array}$ & 70.6 & 100 & 100 \\
\hline $\begin{array}{l}\text { This project will help my company to be more competitive in the domestic market for light-duty vehicles than would have occurred } \\
\text { without involvement in the research and development effort. }\end{array}$ & 46.6 & 100 & 100 \\
\hline $\begin{array}{l}\text { This project has helped my company to be more competitive in the domestic market for light-duty vehicles than would have } \\
\text { occurred without involvement in the research and development effort. }\end{array}$ & 33.3 & 33.3 & 100 \\
\hline $\begin{array}{l}\text { This project will help my company to be competitive in the international market for light-duty vehicles than would have occurred } \\
\text { without involvement in the research and development effort. }\end{array}$ & 46.6 & 66.7 & 100 \\
\hline $\begin{array}{l}\text { This project has helped my company to be more competitive in the international market for light-duty vehicles than would have } \\
\text { occurred without involvement in the research and development effort. }\end{array}$ & 26.6 & 33.3 & 100 \\
\hline $\begin{array}{l}\text { This project will help the U.S. automotive sector to be more competitive in the domestic market for light-duty vehicles than would } \\
\text { have occurred without involvement in the research and development effort. }\end{array}$ & 70.6 & 75 & 100 \\
\hline
\end{tabular}




\begin{tabular}{|c|c|c|c|}
\hline & $\begin{array}{l}\text { Cast light } \\
\text { metals }\end{array}$ & $\begin{array}{c}\text { Durability } \\
\text { of } \\
\text { composite } \\
\text { structures }\end{array}$ & $\begin{array}{l}\text { Rapid } \\
\text { tooling } \\
\text { process }\end{array}$ \\
\hline $\begin{array}{l}\text { This project has helped the U.S. automotive sector to be more competitive in the domestic market for light-duty vehicles than would } \\
\text { have occurred without involvement in the research and development effort. }\end{array}$ & 64.7 & 75 & 100 \\
\hline $\begin{array}{l}\text { This project will help the U.S. automotive industry to be more competitive in the international market for light-duty vehicles than } \\
\text { would have occurred without involvement in the research and development effort. }\end{array}$ & 58.8 & 100 & 100 \\
\hline $\begin{array}{l}\text { This project has helped the U.S. automotive industry to be more competitive in the international market for vehicles than would } \\
\text { have occurred without involvement in the research and development effort. }\end{array}$ & 41.2 & 25 & 100 \\
\hline
\end{tabular}


Table 4.5 provides a summary of the NRC indicators for each project. Publications varied considerably, but this appears to be based primarily on the extent of involvement by private sector partners. Some 32 organizations collaborated in the cast light metals project, while only one national laboratory and the Big 3 automakers joined in the durability of composite structures project. Like our previous analysis, none of the projects had outside review panels, although the projects did have the benefit of steering committee review. In 2001, however, an independent outside panel reviewed the ALM program within DOE, and NAS recently evaluated FreedomCAR's predecessor, the Partnership for a New Generation of Vehicles (PNGV) program (NAS, 2001b). The participants felt that each R\&D project improved U.S. international competitiveness. The United States is leading in R\&D for the durability of composite structures, while it is behind in cast light metals R\&D. There were mixed responses on whether the United States is leading in research in rapid tooling processes.

Table 4.5. National Research Council Indicators

\begin{tabular}{lcccc}
\hline \multicolumn{1}{c}{ Project } & $\begin{array}{c}\text { Number of } \\
\text { publications } \\
\text { produced. }\end{array}$ & $\begin{array}{c}\text { Did it use an } \\
\text { outside review } \\
\text { panel? }\end{array}$ & $\begin{array}{c}\text { Did it improve } \\
\text { U.S. } \\
\text { international } \\
\text { competitiveness? }\end{array}$ & $\begin{array}{c}\text { Is the United } \\
\text { States leading in } \\
\text { research in this } \\
\text { field? }\end{array}$ \\
\hline $\begin{array}{l}\text { Cast light metals } \\
\begin{array}{l}\text { Durability of } \\
\text { composite } \\
\text { structures }\end{array}\end{array}$ & $44^{*}$ & No & Yes & No \\
$\begin{array}{l}\text { Rapid tooling } \\
\text { process }\end{array}$ & 35 & No & Yes & Yes \\
\hline
\end{tabular}

*Source: Fitzsimmons, 2001, see page 88.

\subsection{ECONOMIC ANALYSES}

As outlined in Section 2.3, the economic analyses have two monetary components. The first component, addressed in Sections 4.3.1 through 4.3.5, pertains to the benefits derived from the commercialization of the technologies; we calculated a social benefit-cost ratio. The higher the market penetration of new vehicles that benefit from the projects (e.g., vehicles that have higher amounts of cast aluminum parts due to design optimization or rapid tooling developments), the greater the benefits that can be attributed to the projects. The second monetary calculation relates to the person-year and cost savings analysis. These components are covered in Section 4.3.6. 


\subsubsection{Social Benefit-Cost Analysis}

The benefit estimation in the social benefit-cost approach has three components. The first component, discussed in Section 4.3.2, addresses the potential market penetration of new vehicles that contain materials and/or parts that can be directly attributed to the projects. The project benefits are estimated based on the differential over the normal pace of technology by taking into consideration the specific contribution that the project made to the commercialization of a technology application. For this project, market penetration rates are forecast out to the year 2025, with the consideration of starting year of benefits two years into the future, i.e., 2004, to include implementation costs due to adoption of the technology (as discussed earlier). The second component addresses benefits gained as the new vehicles are adopted in the marketplace. As laid out in Section 4.3.3, three categories of benefits are assessed: energy, environmental, and security for mainly four life cycle stages (i.e., extraction, processing, manufacturing, and use) under three different benefit scenarios. The third component, described in Section 4.3.4, combines the results of the market penetration forecast and the benefits list into three benefit scenarios, where benefits are projected annually out to the year 2025 and discounted to net present value terms (i.e., in 2002 dollars). Using the estimated net present value of the project benefits and costs, benefit-cost ratios for the projects under three different scenarios are finally estimated in Section 4.3.5.

It should be pointed out that the benefits and costs assessed here are social benefits and costs, not the benefits and costs that would be considered by a private sector firm in determining potential returns-on-investment associated with these projects. Included in the social benefits category are benefits that are rarely if ever included in private sector financial calculations, such as social environmental benefits derived from the reduction of the emission of greenhouse gases and criteria air pollutants. In addition, in this evaluation we have included national security benefits associated with reducing the nation's need for oil. Because the category of social benefits, by definition, encompasses a broader range of benefits than does the category of private sector benefits, the magnitude of the social benefits gained from these types of government activities are typically much larger than benefits potentially accruable to firms.

By calculating a social benefit-cost ratio, we are not calculating a return-on-investment that participating private sector companies might receive from commercialization of project products. We do not know how much it will cost companies to commercialize and market the products nor we know to what extent the use of products in new vehicles will increase market share of these vehicles for those companies. We also do not know if use of the products in new vehicles will allow companies to increase prices of their vehicles, thereby possibly increasing profits gained from selling each new vehicle. Without such knowledge, we have no basis upon which to calculate private sector return-on-investment rates associated with these projects. 


\subsubsection{Market Penetration}

\subsubsection{Design and Product Optimization for Cast Light Metals}

The U.S. metal casting industry shipped nearly 15 million tons of castings in 1999, of which aluminum castings represented $13 \%$ of total shipments, mostly to the automobile industry (Kanicki, 2000). The average aluminum content in automobiles in 1999 was $248 \mathrm{lbs} / \mathrm{vehicle}$, and this average is projected to reach $375 \mathrm{lbs} /$ vehicle and $350 \mathrm{lbs} /$ vehicle by the years 2015 and 2025, respectively (Schultz, 1999). Most of this increased aluminum content is primarily due to growth in the use of aluminum castings for wheels, engines, and suspension components. During the latter years, the gains for blocks and heads will be offset in part by a big decline in the aluminum penetration for intake manifolds due to the auto industry's shift to using reinforced nylon and other polymers. The other loss will come from the gradual transition of transmission transfer cases to magnesium castings only if low-cost creep resistant alloys are developed.

Use of aluminum castings in automobiles was estimated for two cases, i.e., with and without the contribution of the given project; the difference between these estimates provided the net estimate of project benefit in terms of increased annual aluminum castings use in light-duty vehicles. In 1999, castings contributed $79 \%$ of total automotive aluminum use. Aluminum castings in automobiles are projected to increase from $196 \mathrm{lbs} / \mathrm{vehicle}$ to $259 \mathrm{lbs} / \mathrm{vehicle}$ during the 1999-2009 period (Schultz, 1999). Beyond 2009, the forecasts of aluminum castings were based on the projections of total aluminum content in automobiles by Schultz as noted above. We assumed that half the increase in total aluminum content between 2010 and 2015 would come from castings, whereas the decline in projected total aluminum content during 2016-2025 will be at the expense of castings content. During this period, castings are projected to experience twice the decline of total aluminum content (assuming thereby that the wrought aluminum content will continue to increase during the entire forecast period). It is estimated that the share of aluminum castings in total automotive aluminum use will decline from $74 \%$ in 2010 to $65 \%$ in 2025 .

It is assumed here that increasing cast design optimization and product capabilities will help to stop the future downward trend of aluminum use (as forecasted by Schultz, 1999) with the increased structural aluminum castings applications. Major aluminum casting components such as engine blocks, cylinder heads, and transmission cases currently have a market penetration rate of $22 \%, 75 \%$, and $88 \%$, respectively (Schultz, 2001). When considering other potential automotive applications such as structural, drivelines, and interiors, the estimated maximum potential aluminum castings use is $320 \mathrm{lbs} / \mathrm{vehicle}$. Here we assume this maximum potential use is achieved by the end of the forecast period, i.e., 2025. This maximum market potential was first estimated by assuming the potential penetration of this market to be low until 2006. Beyond 2006, market penetration was estimated using the widely accepted logit model of technology 
diffusion, adapted by Edwin Mansfield (Mansfield, 1995). ${ }^{8}$ For any given year, only $10 \%$ of the difference between the maximum market potential and baseline (i.e., business as usual) was attributed to this project. This differential market penetration approach for the benefit estimation is different from the five-year rule-of thumb used in our first study, and it is likely to cause a conservative benefit estimate as the consideration has been given here to the specific project contribution to the overall penetration of the technology (i.e., aluminum castings in this case). However, the benefit estimate is sensitive to the percentage difference considered in this analysis.

This assignment of benefits is concurrent with information from our respondents, and consider that this project examined only structural castings. In addition, die castings that contribute about $49 \%$ of total automotive aluminum castings use today as noted below, were not included in this work. The forecasts of new light-duty vehicle sales are based on the Energy Information Administration (EIA) 2001 Reference Case Energy Outlook for the period 2005-2020 (EIA, 2001), which were further extrapolated for the years 2021 to 2025. These new light-duty vehicle sales forecasts are used to estimate the additional quantity of aluminum castings demand resulting from this project.

Figure 4.1 shows the projected amount of aluminum castings content per vehicle both with and without the DOE project benefit under consideration during 2002-2025. These projections for the five specific years are also shown in Table 4.6. The increase in aluminum castings content resulting from the project is estimated to be less than $1 \mathrm{lb} /$ vehicle during the first few years of the forecast period to about $10 \mathrm{lbs} /$ vehicle by the end of the forecast period. The estimated quantity of additional aluminum castings due to this project are also shown in this figure. The benefits of this project will result in less than $20 \mathrm{M}$ lbs of additional aluminum castings annually during much of this decade, but will increase to about $150 \mathrm{M} \mathrm{lbs}$ by the end of forecast period. The growth in project benefits during this decade is estimated to be quite low but increases to a significantly higher rate beyond 2015. Note that aluminum casting shipments in 2001 are estimated to be 3.74B lbs-most of which are for the automobile industry-with a projected annual long-term growth rate of around 4\% (Kirgin and Lessiter, 2002).

\footnotetext{
${ }^{8}$ The Mansfield model estimates the proportion of potential users $P$ who have adopted the new technology by time $t$ as follows:

$$
P(t)=\left[1+e^{(a-b t)}\right]^{-1}
$$

where $a$ and $b$ are the location and shape parameters, respectively. The ratio of $a$ to $b$ specifies the length of time $t$ it takes for $P(t)$ to reach $50 \%$ of its "designated" potential market.
} 


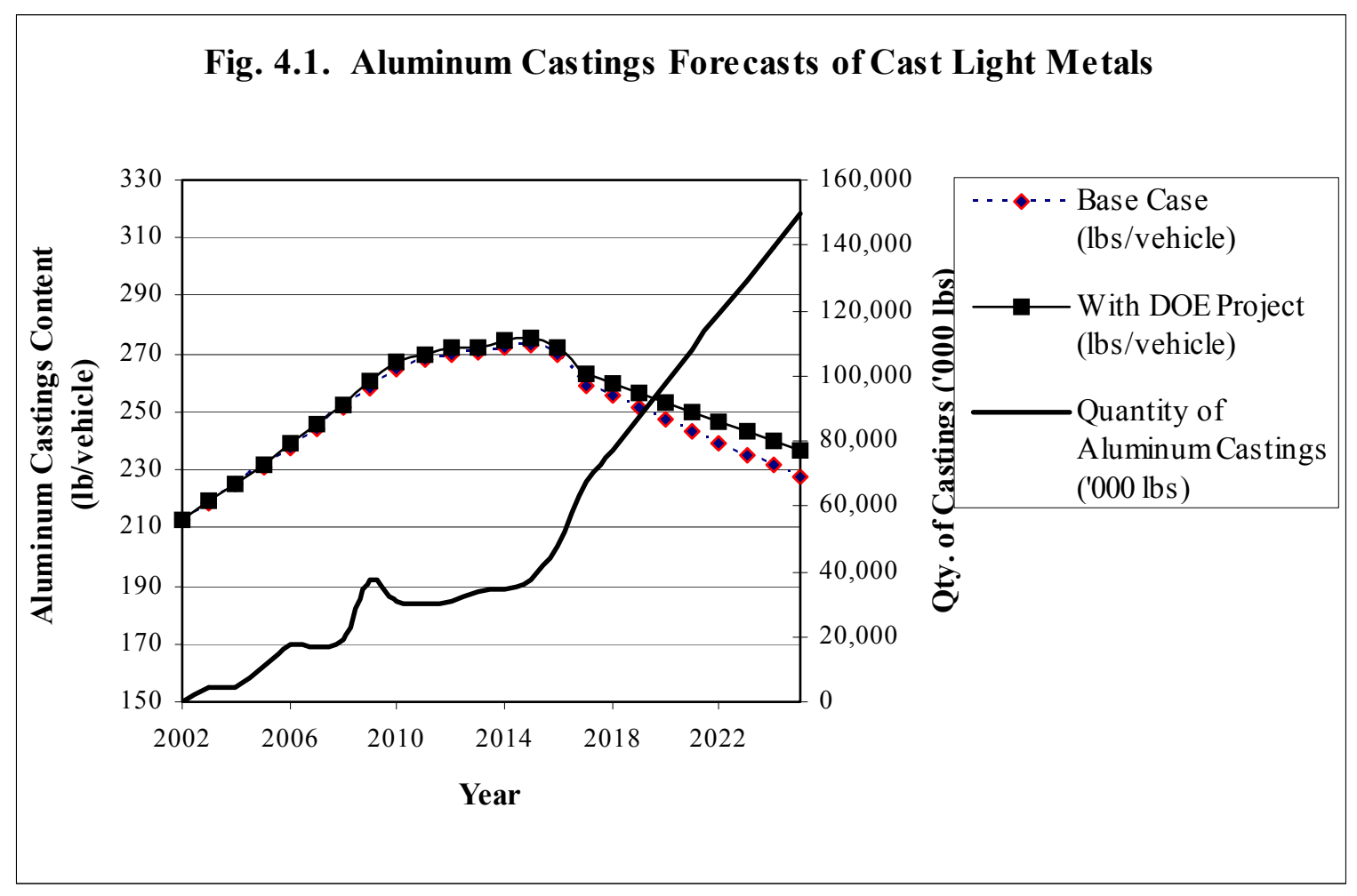

Table 4.6. Five-Year Aluminum Castings Forecasts of Cast Light Metals Project*

\begin{tabular}{|c|c|c|c|c|}
\hline \multirow{2}{*}{ Year } & $\begin{array}{c}\text { No. of Light- } \\
\text { duty Vehicles } \\
\text { (M) }\end{array}$ & \multicolumn{2}{|c|}{$\begin{array}{c}\text { Castings Content } \\
\text { (lbs/vehicle) }\end{array}$} & \multirow{2}{*}{$\begin{array}{c}\text { Project Benefit } \\
\text { (M lbs of castings) }\end{array}$} \\
\cline { 3 - 4 } & 15.4 & Baseline & With Project & \\
\hline 2004 & 14.7 & 225 & 225 & 4.5 \\
\hline 2010 & 15.9 & 265 & 267 & 31.1 \\
\hline 2015 & 16.2 & 273 & 276 & 37.2 \\
\hline 2020 & 16.2 & 247 & 253 & 98.0 \\
\hline 2025 & 227 & 237 & 149.7 \\
\hline
\end{tabular}

*Due to rounding of the values, the estimates shown based on other columns in the table may not be exact. 


\subsubsection{Durability of Lightweight Composite Structures}

As discussed earlier, the results of this project have been instrumental in the commercial automotive structural application of pickup boxes of light-duty trucks such as the GM Chevy Silverado and the Ford Explorer Sport Trac; therefore, no baseline has been considered in this case. Although initial benefits of this project have been demonstrated in the open cargo areas of pickup trucks, it is very likely that the benefit will extend to semi-structural components (e.g., body sides) of passenger cars as well. It is assumed here that this project would contribute only a fraction of the overall market penetration of this technology in this specific commercial application of glass-reinforced polymer composites, which is based on the assumptions made for the manufacturing of composite automotive structures market forecast made in a previous study (Das, Peretz and Tonn, 2001).

An initial estimate by the developer of the composite molding technology-P4/structural reaction injection molding (SRIM) used for open cargo areas of pickup truck beds-indicates the annual volume of composite truck beds of 220,000 units or 50,000 metric tons by 2004 (Composites Technology, 2000). The market penetration rate of composite truck beds was based on the EIA 2001 reference-case forecasts of the number of pickup trucks in North America (EIA, 2001), the parameters of the logit model of the technology diffusion model calibrated to the developer's 2004 forecasts, and limiting the share of this technology in the open cargo area pickup truck market to $50 \%$ or less by 2025 . It is unlikely that the maximum penetration rate could be any higher than the assumed $50 \%$ because of competition from advancements in steel and aluminum. Also, composites have been found to be cost-effective only in low- to medium-volume applications. To translate this forecast of units into a forecast of production volume for glassreinforced polymer composites, the analysis assumes $250 \mathrm{lbs}$ of composites per truck and the estimated light-duty vehicle market as discussed above.

The market potential of composite semi-structural applications in cars is estimated based on the EIA 2001 reference-case forecast of new car sales, and by using Mansfield's technology diffusion model limiting the total penetration rate of this technology to not more than 5\% of new cars by 2015 and $10 \%$ by 2025 , the end of forecast period. Although it is likely that the number of cars using composites in semi-structural applications will be higher than is assumed here, the higher amount of material (i.e., $370 \mathrm{lbs}$ used in body-in-white structure) for the estimation of annual production volume of composites is assumed here to capture those impacts. The durability of lightweight composite structures is the enabling technology and also one of several projects instrumental in the successful commercialization of composite open cargo areas in pickup truck applications. Other projects covered several composite manufacturing aspects including preforming, bonding, and nondestructive evaluation and inspection techniques. Each of the survey participants was asked about the contribution this project made to the overall success in the composite structure commercialization of pickup trucks. All respondents felt that this project was crucial to the overall project goal; further some felt that this project contributed $25 \%$ to the overall commercialization project. This factor of contribution was applied to the above annual estimated production volume of glass-reinforced polymer composites for both open 
cargo areas of pickup trucks and semi-structural components in cars to calculate the composites volume attributable to this specific project under consideration here.

The market forecasts for glass-reinforced polymer composites for open cargo truck boxes and semi-structural passenger car applications are shown in Figure 4.2. Table 4.7 shows also these forecasts for the five specific years. The combined market for this technology will grow from $13 \mathrm{M} \mathrm{lbs}$ in 2002 to about $143 \mathrm{M}$ lbs by 2025 . The semi-structural automotive component application is assumed to grow at a significantly higher rate during the latter years of the forecast period, increasing from $37 \mathrm{M} \mathrm{lbs}$ in 2015 to $74 \mathrm{M}$ lbs by 2025 . Although these estimates represent the market forecasts limited to the single project under consideration here, they do represent a significant growth in structural automotive composites application. In comparison, of the $318 \mathrm{M}$ lbs of automotive composites manufactured in 1999 (projected to be 370M lbs in 2002, Rusnak, 2002), about 353,000 lbs were resin transfer molding (RTM) components, used mainly for automotive structural component manufacturing, for light-duty vehicle applications (Automotive Composites Alliance, 2000).

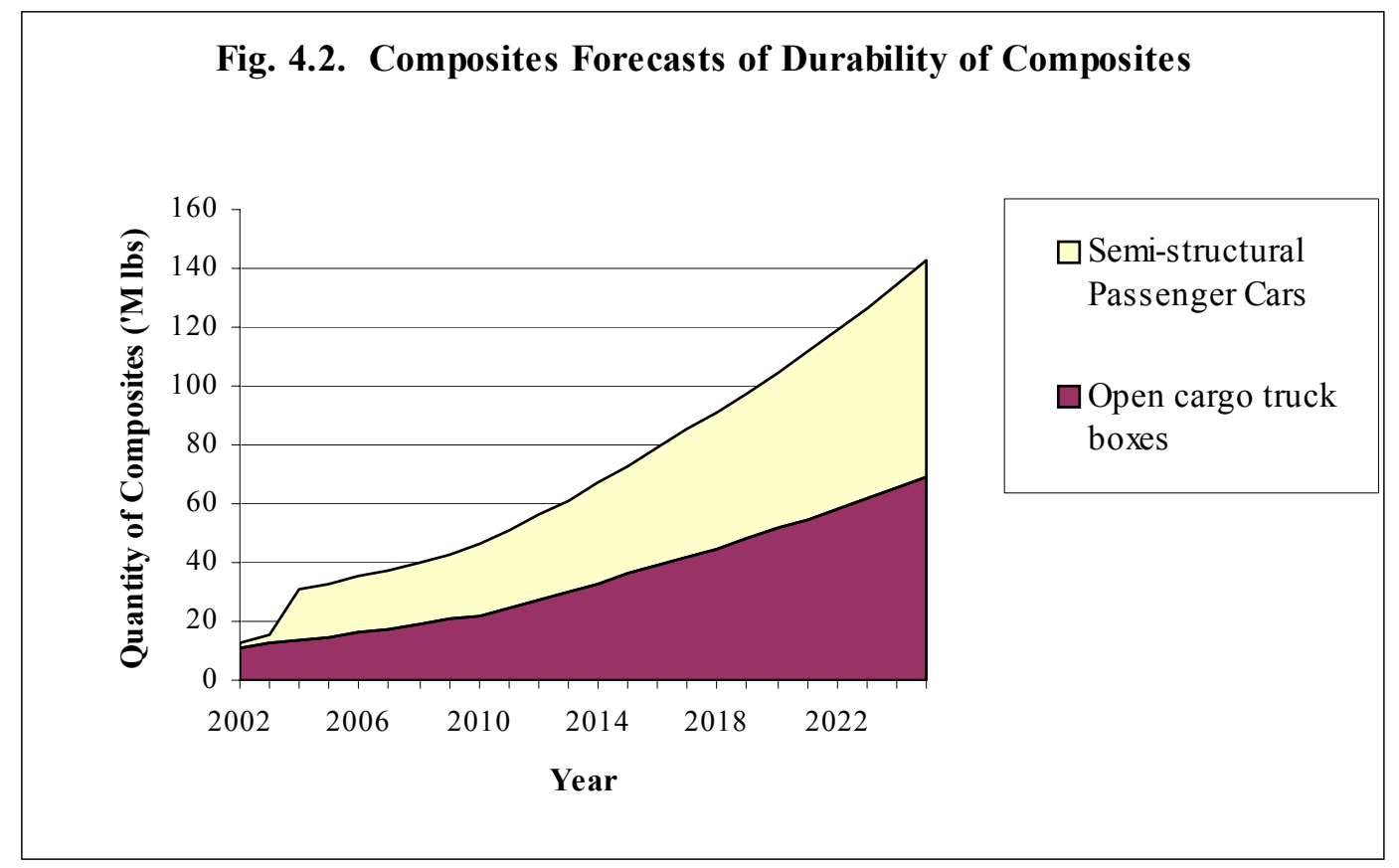


Table 4.7 Five-Year Composites Forecasts of Durability Composites Project

\begin{tabular}{|c|c|c|c|c|}
\hline \multirow{2}{*}{ Year } & \multicolumn{2}{|c|}{ Pickup Truck } & \multicolumn{2}{c|}{ Passenger Car } \\
\cline { 2 - 5 } & Sales (M) & $\begin{array}{c}\text { Composites Use } \\
\text { (M lbs) }\end{array}$ & Sales (M) & $\begin{array}{c}\text { Composites Use (M } \\
\text { lbs) }\end{array}$ \\
\hline 2004 & 2.33 & 14 & 8.09 & 17 \\
\hline 2010 & 2.16 & 22 & 7.51 & 24 \\
\hline 2015 & 2.27 & 36 & 8.03 & 37 \\
\hline 2020 & 2.24 & 52 & 8.11 & 53 \\
\hline 2025 & 2.20 & 69 & 7.99 & 74 \\
\hline
\end{tabular}

\subsubsection{Rapid Tooling for Functional Prototyping of Metal Mold Processes}

The impacts of rapid tooling of metal mold processes will be limited mainly to the die casting process, but will apply to both aluminum and magnesium castings. Thus, the increased market penetration of magnesium die castings will not reduce the impact of the metal mold process (as might otherwise occur as magnesium begins to replace aluminum). To account for this, we assumed a non-declining trend in the aluminum die castings market. Additionally, the total aluminum die casting market is $0.9 \mathrm{M}$ tons, compared to 37,500 tons for the magnesium die castings in 1999 (Udvardy, 2001). The automotive industry is estimated to have contributed 69\% and $90 \%$ of total die casting markets of aluminum and magnesium, respectively, in 2000 (Twarog, 2001). The annual shipments of aluminum die castings in 1999 are estimated to be $49 \%$ of total aluminum castings use in North American automobiles (Ducker Research Company, 1998). In terms of percentage use of aluminum die castings in specific application areas, transmission, driveline, steering, and electrical components contribute more than 55\% of total castings use.

The forecast for aluminum (and magnesium) automotive die castings, even without DOE project benefits, is assumed to increase during the entire forecast period, i.e., 2002-2025. The first step in making this estimate was to assume a continued upward trend in aluminum castings content beyond 2015. (Again, this assumption is made because magnesium die castings-the eventual substitute for aluminum die castings-also benefited from this project.) The continued upward trend results in aluminum castings content increasing from $213 \mathrm{lbs} /$ vehicle in 2002 to 320 $\mathrm{lbs} /$ vehicle in 2025 , estimated in a similar way as for the total castings for the cast light metals project with the DOE project benefits. The amount of die casting without the project benefit was then estimated by applying the share of aluminum die castings to this forecasted amount of total castings. The share of aluminum die castings to total aluminum castings was assumed to decline 
from $49 \%$ to $48 \%$ during $2002-2009$, and $48 \%$ to $42 \%$ during the remaining 16 years of the forecast period, mainly due to the growth of structural aluminum castings parts such as engine blocks and cylinder heads manufactured by permanent mold casting. Although the share of aluminum die castings is projected to decline in the future, but due to the projected increasing trend in total aluminum castings content (as discussed earlier), the amount of die castings per vehicle is thus estimated to increase from $120 \mathrm{lbs} /$ vehicle in 2002 to $134 \mathrm{lbs} /$ vehicle in 2025 without the project benefit. Note that this increasing trend of aluminum die castings is due to consideration of magnesium die castings as a part of aluminum castings in this analysis. The forecasted low annual rate of aluminum die cast parts increase is consistent with the annual $1 \%$ to $2 \%$ growth rate forecasted for the coming five years by the North American die casting industry (Udvardy, 2001).

Rapid tooling-12 weeks compared to the standard 48 weeks-will facilitate the penetration of die cast parts into the automotive market. It is assumed here that this project would enable the capture of $10 \%$ of the new potential die castings market by the year 2025, where the increase would follow Mansfield's logit model of technology diffusion as before. The amount of aluminum die castings is estimated thus to increase from $121 \mathrm{lbs} /$ vehicle in 2002 to 148 $\mathrm{lbs} /$ vehicle in 2025, with the increase due to this project being about $14 \mathrm{lbs} /$ vehicle maximum in 2025. As before, the difference between the estimated aluminum die castings with and without the project provided the estimate of the project benefit, in terms of increased annual die castings use per light-duty vehicle. Other assumptions regarding forecasts of light-duty vehicle sales are as before and are used to forecast the annual increase in aluminum die castings due to the successful implementation of this project.

Figure 4.3 shows the projected amount of aluminum die castings content per vehicle both during 2002-2025 with and without the DOE project benefit under consideration. These projections for the five specific years are also listed in table 4.8. Unlike the cast light metals project, there is a steady increasing trend in aluminum die castings content, reaching the projected benefits of 14 $\mathrm{lbs} / \mathrm{vehicle}$ by the end of forecast period. A similar trend is also being depicted for the estimated quantity of additional aluminum castings due to this project, also shown in this figure. The benefits of this project will result in less than $20 \mathrm{M}$ lbs during the initial years of the forecast period, but increasing to $218 \mathrm{M} \mathrm{lbs}$ by the end of forecast period. Note that the recent estimate indicates annual aluminum die casting shipments to the automotive industry to be $1.2 \mathrm{~B} \mathrm{lbs}$, projected to increase at a relatively slow rate of $1 \%$ to $2 \%$ during the next few years (Udvardy, 2001). 


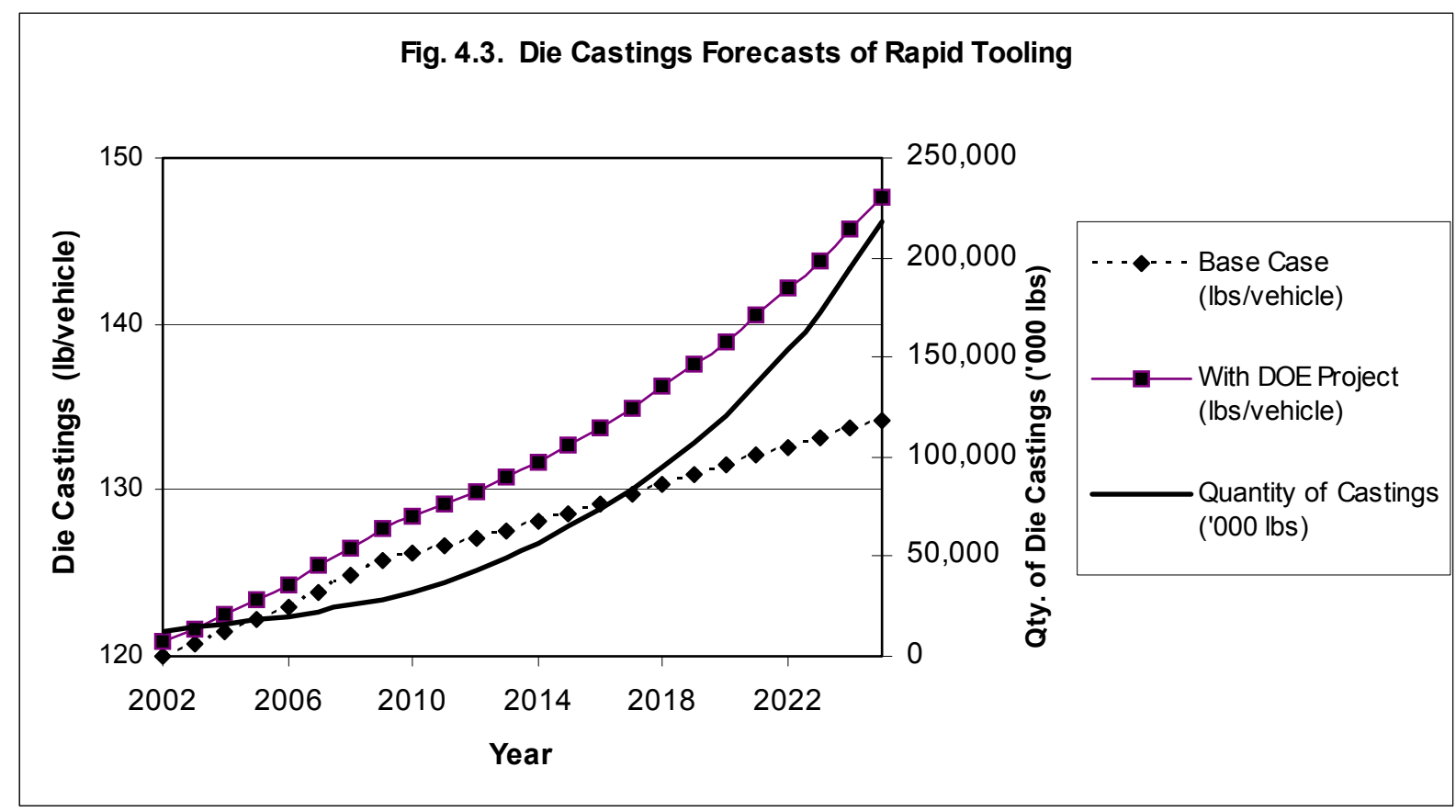

Table 4.8. Five-Year Automotive Die Castings Forecasts of Rapid Tooling Project

\begin{tabular}{|c|c|c|c|c|}
\hline \multirow[t]{2}{*}{ Year } & \multirow{2}{*}{$\begin{array}{l}\text { No. of Light- } \\
\text { duty Vehicles } \\
\text { (M) }\end{array}$} & \multicolumn{2}{|c|}{$\begin{array}{c}\text { Die Castings Content } \\
\text { (lbs/vehicle) }\end{array}$} & \multirow[t]{2}{*}{$\begin{array}{c}\text { Project Benefit } \\
\text { (M lbs of die castings) }\end{array}$} \\
\hline & & Baseline & With Project & \\
\hline 2004 & 15.4 & 121 & 122 & 16.0 \\
\hline 2010 & 14.7 & 126 & 128 & 32.6 \\
\hline 2015 & 15.9 & 129 & 133 & 65.1 \\
\hline 2020 & 16.2 & 131 & 139 & 121.0 \\
\hline 2025 & 16.2 & 134 & 148 & 217.9 \\
\hline
\end{tabular}

*Due to rounding of the values, the estimates shown based on other columns in the table may not be exact. 


\subsubsection{Energy, Environmental, and Security Benefits}

This section addresses the benefits attributable to the new vehicles projected to be on the road based on the analysis presented above. First to be considered are energy and environmental benefits. Energy benefits will accrue because the new vehicles will be lighter than today's vehicles. Reduced weight leads to reduced energy consumption, holding constant vehicle miles driven, driving styles, and road and weather conditions. The vehicle-use benefits estimation procedure takes into account the actual number of vehicles driven annually with different ages, assuming a vehicle life of 10 years and 10,000 miles driven annually. Environmental benefits will accrue during the use of these vehicles because for every gallon of gasoline saved there will be corresponding reductions in air pollution emissions, particularly carbon emissions. In this analysis, specific benefits assessed are gallons of gasoline saved and reductions in carbon dioxide $\left(\mathrm{CO}_{2}\right)$, carbon monoxide $(\mathrm{CO})$, particulate matter $\left(\mathrm{PM}_{10}\right)$, nitrogen oxides $\left(\mathrm{NO}_{\mathrm{x}}\right)$, and sulfur oxides $\left(\mathrm{SO}_{\mathrm{x}}\right)$ emissions. Environmental benefits considered at the use phase include both upstream benefits due to lower required fuel production and tailpipe emissions mainly restricted to carbon emissions. The correlation between improved fuel economy and reduced regulated criteria pollutant emissions appears unclear in today's literature. The tailpipe emissions are measured on a grams-per-mile basis and tailpipe criteria emissions are set irrespective of vehicle fuel economy, so it's argued that reduced criteria tailpipe emissions due to improved fuel economy may not be significant, or even existent.

Most reductions of environmental burdens are associated with the use phase of the automobile. To gain insights into other potential benefits of using new lightweight materials in vehicles, it is useful to adopt a life-cycle view of automobiles and their components. Within the life-cycle framework, our analysis considers the extraction of raw materials from the earth, the processing of raw materials into refined forms, the manufacture of automobile parts and components from processed materials, and the recycling, reuse, or disposal of automobile parts and components of end-of-life vehicles. Environmental emissions and issues are associated with each of these phases, in addition to the vehicle-use phase addressed in the previous paragraph. Because it can be an enormous undertaking to track every material at every stage in the life cycle, this research focuses on only four of the five phases: extraction, materials processing, manufacturing, and use. These phases represent most of the environmental emissions associated with the automobile industry.

Thus, the life-cycle assessment task is centered around examining the environmental consequences of replacing steel components in vehicles with aluminum castings, and more widespread use of glass composites resulting from the development of design guidelines to ensure durability of composites. Staff at the University of Tennessee's Center for Clean Products and Clean Technology provided estimates for the amounts of energy used and environmental pollutants emitted in producing one pound of steel, aluminum, and glass composite material. These numbers had been previously developed during other life-cycle assessment projects at the Center, including two projects supported by DOE and managed by ORNL related to the PNGV program. These numbers were translated into savings in energy use and environmental emissions 
per pound of new material used in the vehicles for an aggregate extraction, processing, and manufacturing stage, and for the use stage. These translated numbers are shown in Table 4.9.

Table 4.9. Energy and Environmental Savings Per Pound of Material Used to Replace Steel

\begin{tabular}{lcc|cc}
\hline \multicolumn{1}{c}{$\begin{array}{c}\text { Project Area } \\
\text { Benefit Category }\end{array}$} & \multicolumn{2}{c}{ Aluminum } & \multicolumn{2}{c}{ Glass Composites } \\
\cline { 2 - 4 } & $\begin{array}{c}\text { Extraction, } \\
\text { processing, } \\
\text { manufacturing }\end{array}$ & Vehicle use & $\begin{array}{c}\text { Extraction, } \\
\text { processing, } \\
\text { manufacturing }\end{array}$ & Vehicle use \\
\cline { 2 - 4 } Energy (mmBtu) & -0.0974 & 0.1569 & -0.0053 & 0.0857 \\
$\mathbf{C O}_{\mathbf{2}}(\mathbf{l b s})$ & -9.3978 & 28.1342 & 1.2570 & 15.3684 \\
$\mathbf{C O}(\mathbf{l b s})$ & -0.0012 & 0.1093 & -0.0056 & 0.0445 \\
$\mathbf{P M}_{\mathbf{1 0}}(\mathbf{l b s})$ & -0.0178 & 0.0035 & 0.0279 & 0.0018 \\
$\mathbf{N O}_{\mathbf{x}}(\mathbf{l b s})$ & -0.0414 & 0.0155 & -0.0143 & 0.0081 \\
$\mathbf{S O}_{\mathbf{x}}(\mathbf{l b s})$ & -0.0466 & 0.0222 & -0.0145 & 0.0122 \\
\hline
\end{tabular}

Table 4.9 illustrates that the energy and environmental costs and benefits associated with new lightweight vehicles, which employ more aluminum and/or glass composites, are complex. Note that environmental benefits at the vehicle-use phase include both fuel production and vehicle use. As discussed above, criteria pollutant emission benefits at this phase include only fuel production. Generally, there are appreciable energy and environmental emission savings in the use phase. However, with respect to the extraction, processing, and manufacturing phases, the picture is different. Aluminum, in particular, requires more energy to process than steel. The extraction of the raw materials needed for aluminum is also more energy intensive than for the components of steel. The energy intensity of aluminum at this stage depends on its recycled content, which is assumed to be $11 \%$ for the values indicated in Table 4.9. Because of the increase in energy needs, more environmental emissions are associated with extraction and processing of aluminum than with steel. Note that for criteria air pollutants, there is a net increase in costs rather than savings for aluminum. On the other hand, emissions are generally lower during these phases for glass composites.

In addition to understanding the magnitude of the energy and environmental impacts, we need to determine the monetary value of the impacts. In other words, what is the value of reducing fuel consumption by a gallon? Estimating these monetary values is a difficult and controversial exercise, one of the main criticisms of the use of benefit-cost analysis in the environmental field. 
Nevertheless, many attempts have been made to estimate these values. Riggert et al. (1999) have done a thorough job of reviewing the literature to distill the ranges in benefit estimates related to environmental emissions (see also NAS, 2001a). EIA publishes price forecasts for energy products. Using these sources, we developed three value scenarios, indicated in Table 4.10. For example, the value estimates for saving a gallon of gasoline range from a low of $\$ 1.33$ per gallon to a high of $\$ 2.00$ per gallon. Gasoline savings are associated with the vehicle-use phase whereas oil savings are associated with the extraction, processing, and manufacturing stage. Although coal, natural gas, and electricity are the most common energy types used at the extraction, processing, and manufacturing stage, oil represents the average energy value used in this analysis (i.e., \$/Btu).

Table 4.10. Energy and Environmental Emission Values Scenarios

\begin{tabular}{rccc}
\hline & Base values case & Moderate values case & High values case \\
\hline Oil (\$/barrel) & 25 & 30 & 40 \\
Oil Security (\$/barrel) & 3 & 10 & 20 \\
Gas (\$/gallon) & 1.33 & 1.63 & 2.00 \\
$\mathbf{C O}_{\mathbf{2}}$ (\$/ton) & 7 & 27 & 55 \\
$\mathbf{C O}$ (\$/ton) & 920 & 1000 & 1086 \\
$\mathbf{P M}_{\mathbf{1 0}}$ (\$/ton) & 40 & 1000 & 9953 \\
$\mathbf{N O}_{\mathbf{x}}$ (\$/ton) & 44 & 600 & 8143 \\
$\mathbf{S O}_{\mathbf{x}}$ (\$/ton) & 110 & 200 & 2030 \\
\hline
\end{tabular}

Assessing the value of the environmental benefits associated with the reduction of greenhouse gas (GHG) emissions and air pollutants is a difficult and controversial process. It is also an expensive process. This project did not have the resources to conduct original valuation research, so we turned to the existing literature. A particularly useful report was prepared for the State of Vermont to help it assess the benefits of its low income home weatherization program (Riggert et al., 1999). Similar to lightweighting vehicles, making homes more energy efficient has the added benefits of reductions in GHG emissions and air pollutants. The authors of that report, also unable to conduct original valuation research, conducted an exhaustive review of the valuation literature to develop ranges of values associated with reductions in GHG emissions and air pollutants. We built our valuation estimates, in part, upon their work, knowing that it really does not matter from a valuation context how such reductions were accomplished. We also based our 
valuation estimates on the NAS (2001a) report evaluating DOE's energy efficiency and fossil energy programs, which also based its estimates on a literature review.

As Table 4.10 suggests, the range in values is extreme for several of the environmental emissions. The base and high values cases represent the published ranges. The moderate case represents values that are more realistic than the low and high values cases. The range in valuation estimates is due to two main factors. First, different researchers use different methods. Thus, ranges are inevitable. Second, some valuation estimates focus on the market prices of tradable emissions permits whereas other estimates focus on human health benefits, reflected here in the high values case, particularly for criteria air pollutants. In almost all cases, the market prices of tradable emission permits, which reflect the cost to industry to meet emissions targets, are much lower than the estimated social benefits of reduction of GHG and air pollutants. However, estimating social benefits is much more controversial and entails much more uncertainty than does estimating the value of emission permits. We have tried to find a compromise among the ranges of values and different perspectives within our adoption of midrange valuation estimates.

The security benefit resulting from the prevention or mitigation of macroeconomic losses from energy disruptions has also been considered in the analysis here. The security benefit representing a reduction in the cost of an oil price shock is also shown in Table 4.10 in terms of $\$ /$ barrel. A wide variation in the reported values of oil price shocks exists in the literature today. The base value case assumes cartel pricing, whereas the high value case is based on price shocks that have cost the U.S. economy during the past 28 years (Leiby et al.,1997). Since oil use occurs mainly at the use life-cycle stage, the security benefit is estimated only on that stage by converting total energy use into equivalent barrels of crude oil.

\subsubsection{Market Penetration Benefit Estimates}

Table 4.11 presents the energy, environmental, and security net present value benefits (in 2002 dollars) attributable to the projects, given the market penetration forecasts out to the year 2025 , the values presented above, and a 7\% discount rate, which is the current rate recommended by the Office of Management and Budget (OMB, 1996) for use in the benefit-cost analysis of regulatory actions required by the Executive Order. Benefits are presented for the three cases described above. As discussed before, the annual benefits are considered for the period 20042025 , without consideration of the first two years of the benefits to correct for implementation costs of adopting the new technology. Environmental benefits include both carbon and criteria pollutant emissions as well, and the benefits due to carbon are also shown separately in this table.

As expected, the energy and environmental benefits for the extraction, processing, and manufacturing phases are negative in several instances. However, the use-phase benefits outweighed these negative benefits in most cases causing net positive benefits. Energy benefits are significantly higher than environmental and security benefits, although quite a controversy 
still exists over the value of the impacts in the latter case. Due to the energy-intensive nature of the aluminum manufacturing process, total benefits are considerably lower (particularly in the "high values case") in the case of the first and last projects related to aluminum listed in this table. For the same reason and net criteria pollutant benefits being negative (as shown in Table 4.9), total environmental benefits are lower than carbon emissions alone in the case of these two aluminum related projects. In fact, under the "high values case," the emission values for the criteria pollutants are significantly higher than carbon emission values, resulting in overall negative environmental benefits for these two projects. The estimated benefits are greatest for the durability of composite structures project. The forecast period under consideration will affect the estimated benefits, and it is particularly important in the case of two aluminum-related projects as more use phase benefits are realized later in the forecast period with a greater number of lightweight vehicles in the vehicle fleet. A recent study indicates that aluminum-intensive vehicles containing aluminum sheets takes more than 15 years to achieve life-cycle equivalence emissions at the fleet level with conventional steel vehicles (Das, 2000).

Table 4.11. Energy, Environmental, and Security Benefit Results (2002\$ millions)

\begin{tabular}{|c|c|c|c|c|}
\hline Projects & Energy & Environment* & Security & Total \\
\hline \multicolumn{5}{|c|}{ BASE CASE } \\
\hline Cast light metals & $\$ 231$ & $\$ 21(\$ 22)$ & $\$ 23$ & $\$ 275$ \\
\hline $\begin{array}{l}\text { Durability of composite } \\
\text { structures }\end{array}$ & $\$ 356$ & $\$ 31(\$ 31)$ & $\$ 20$ & $\$ 407$ \\
\hline Rapid tooling process & $\$ 327$ & $\$ 30(\$ 31)$ & $\$ 31$ & $\$ 388$ \\
\hline \multicolumn{5}{|c|}{ MODERATE VALUES CASE } \\
\hline Cast light metals & $\$ 288$ & $\$ 42(\$ 52)$ & $\$ 75$ & $\$ 405$ \\
\hline $\begin{array}{l}\text { Durability of composite } \\
\text { structures }\end{array}$ & $\$ 437$ & $\$ 110(\$ 103)$ & $\$ 66$ & $\$ 613$ \\
\hline Rapid tooling process & $\$ 407$ & $\$ 62(\$ 74)$ & $\$ 104$ & $\$ 573$ \\
\hline \multicolumn{5}{|c|}{ HIGH VALUES CASE } \\
\hline Cast light metals & $\$ 329$ & $-\$ 19(\$ 93)$ & $\$ 151$ & $\$ 461$ \\
\hline $\begin{array}{l}\text { Durability of composite } \\
\text { structures }\end{array}$ & $\$ 534$ & $\$ 267(\$ 202)$ & $\$ 133$ & $\$ 934$ \\
\hline Rapid tooling process & $\$ 467$ & $-\$ 11(\$ 133)$ & $\$ 207$ & $\$ 663$ \\
\hline
\end{tabular}




\subsubsection{Benefit-Cost Ratios}

Table 4.12 contains social benefit-cost ratios for the projects. We calculated these by adding together the monetized energy, environmental, and security benefits and dividing by the project costs. Note that the security benefits considered in the benefit-cost ratios remain quite controversial in the literature today. The project costs indicated in Table 4.12 represent both DOE and private sector contributions to the projects. In every instance, the benefit-cost ratios are substantial. The least project cost and quite high estimated benefits cause the highest benefit-cost ratio in the case of the rapid tooling project. Since the estimated environmental and security benefits are not very high, the resulting benefit-cost ratios (which are also shown in this table) without consideration of these benefits are not significantly lower in most cases than those when all benefits are included. In general, these ratios are at the higher end than those reported by Link and Scott (1998) for five Advanced Technology Projects (ATP), which range from 4 to 85, and Martin et al. (2000) for "Standard Reference Materials for Sulfur in Fossil Fuels," which was 113. However, these ratios appear to be lower than those reported by Chapman and Fuller (1996) for two National Institute of Standards and Technology programs, by Yuracko, Tonn and Morris (1999) for several pollution projects funded by DOE at the Oak Ridge Reservation, and the three earlier ALM projects evaluated (Das, Peretz and Tonn, 2001). Note that life-cycle impacts covering a relatively long forecast period of 25 years was considered for the three projects in this study.

Table 4.12. Benefit-cost Ratios

\begin{tabular}{lcccc}
\hline Project & $\begin{array}{c}\text { Project Cost } \\
\text { (\$ millions) }\end{array}$ & $\begin{array}{c}\text { B-C Ratio* } \\
\text { Base Case }\end{array}$ & $\begin{array}{c}\text { B-C Ratio* } \\
\text { Moderate Case }\end{array}$ & $\begin{array}{c}\text { B-C Ratio* } \\
\text { High Case }\end{array}$ \\
\hline Cast light metals & 5.91 & $46(39)^{*}$ & $69(49)^{*}$ & $78(56)^{*}$ \\
$\begin{array}{l}\text { Durability of composite } \\
\text { structures }\end{array}$ & 9.81 & $42(36)^{*}$ & $63(45)^{*}$ & $95(54)^{*}$ \\
Rapid tooling process & 2.71 & $143(121)^{*}$ & $211(150)^{*}$ & $245(172)^{*}$ \\
\hline
\end{tabular}

*Numbers inside parenthesis indicate benefit-cost ratios without taking into account environmental and security benefits.

\subsubsection{Person-Year and Cost Savings Analysis}

These benefits measure how many person-years and costs were saved by firms participating in the R\&D effort. In each R\&D project, we asked participants approximately how many personyears of research effort participation had saved their companies (to reach the level of efficiency 
they now have in the particular research field). For the cast light metals efforts, seven responded; two indicated less than 1 year; two said 1 to 2 years; and three indicated 3 to 5 years. For the durability of composite structures, the three automaker respondents indicated 6 to 8 years. For the rapid tooling, one respondent indicated 3 to 5 years, while two respondents suggested 6 to 8 years. The averages are presented in Table 4.13. We used the responses to our question on the average person-year cost in the industry (with full benefits) to determine the average cost savings (e.g., average cost savings=average person-years savings times average person-year costs).

Table 4.13. Person-Year and Cost Savings Benefit Estimates

\begin{tabular}{lccc}
\hline & Cast light metals & $\begin{array}{c}\text { Durability of } \\
\text { composite structures }\end{array}$ & Rapid tooling process \\
\hline $\begin{array}{l}\text { Person-year savings } \\
\text { (average per firm) }\end{array}$ & 2.4 & 7 & 6 \\
$\begin{array}{l}\text { Cost savings (average } \\
\text { per firm) }\end{array}$ & $\$ 258,000$ & $\$ 1,225,000$ & $\$ 900,000$ \\
\hline
\end{tabular}

\subsubsection{Economic Analyses Summary}

With regard to the social benefit-cost ratios in section 4.3.5, several qualifications should be noted. The market penetration dates and rates of the technologies are quite uncertain. Significant uncertainties exist related to the values assigned to the reduction of air pollutants and to saving oil and gas. This research only dealt with these uncertainties in a small way by incorporating three different valuation scenarios.

Additional research is needed on valuing reductions in pollutants. Some values in the literature are based on forecasted values for emission permits (e.g., the value of a permit to emit one ton of carbon into the atmosphere) whereas other values focus on valuing the reductions in human deaths and health effects due to reductions in emissions. Both types of estimates are included in this analysis. Whether this is appropriate is a policy discussion beyond our scope of this research effort.

Next, the cost estimates do not fully include the investment costs to be borne by the automobile industry or its suppliers to implement the technologies. These costs could be significant, as they not only would include new capital equipment but could also include costs associated with redesigning manufacturing processes and re-training employees. Including these costs would lower the benefit-cost ratios.

Lastly, the benefits are only forecasted to the year 2025. One can easily imagine that benefits 
could accrue for many years beyond the year 2025 , which would mean that the benefits and ratios are understated. On the other hand, there is the possibility that these technologies could be replaced by even better materials and/or technologies several years hence.

With regard to the monetary savings to firms due to their access to federal funds, the majority of participants did not respond with a dollar value for person-year saved. Hence this savings to industry by access to federal R\&D are likely be underestimated.

\subsection{TRACKING FUTURE BENEFITS}

The three approaches we used for assessing benefits provided useful information for this program evaluation. A question still remains, however, about tracking future benefits associated with the projects because it may be premature to judge the benefits of just-completed or nearly completed projects that could have long-term benefits. Indeed, our participants suggested longterm evaluations, as they did in our previous analysis (Das, Peretz and Tonn, 2001). Here are three suggestions that seem appropriate in this context:

$<$ Publications tracking. Track journal papers and technical reports in process to completion. Researchers can periodically use a citation search engine, such as the Web of Science, to track the number of citations.

$<$ Technology tracking. Check with private-sector producers of materials and manufacturers of vehicles every several years to ascertain whether the technology was commercialized, and if so, how many in-use vehicles benefit from the technology. Evaluators can then prepare updated market penetration forecasts and assessments of spin-off technologies.

$<$ Qualitative innovation tracking. In many instances, new technologies do not pan out as intended but yield huge benefits for other applications or lead to newer and better innovations. In-depth case studies can then document the evolution of applications and new technologies. 


\section{CONCLUSIONS}

This research, which focuses on short-run outputs and long-term outcomes, applies three approaches to assess the benefits attributable to three ALM projects focusing on short-run outputs and long-run outcomes. As in our previous study, each of the three methods appears suitable for this type of evaluation. The qualitative assessment and NRC indicators sufficiently assessed the knowledge benefits derived from these $R \& D$ efforts. The social benefit-cost ratios allow us to monetize the R\&D efforts. In the durability of composite structures and rapid tooling process cases, we could quantify realized benefits as the enabling technology is used by the auto industry.

By using three approaches, we present a comprehensive evaluation assessment of benefits from ALM R\&D efforts. The qualitative assessment is useful for assessing project-level, short-run outputs. The NRC indicators focus on the quality of the research, with both a short- and long-run perspective (particularly the publications). Social benefit-cost analysis addresses commercialization and associated societal benefits, such as energy and security savings and reduction in air pollution.

All three R\&D projects appear to have yielded high levels of benefits. From the qualitative assessment, all met their technical goals, increased knowledge, and led to increased collaboration. It is not likely that these projects would have been undertaken without federal support or at least undertaken as soon or with as much depth as they were. With respect to the NRC indicators, publications and presentations resulted, and U.S. competitiveness appeared to increase as a result of each R\&D effort. The social benefit-cost analysis yielded impressive benefit-to-cost ratios.

Knowledge benefits were achieved as evidenced through the number of publications, presentations, and graduate student effort. Two of the three projects included active participation by universities. and two master theses resulted from one R\&D project. Indeed, one non-monetary benefit of all these projects is related to the enhancement of knowledge value communities (KVCs) in the areas of cast light metals, lightweight composite structures, and rapid tooling. KVCs are also known as communities of practice and epistemic communities and were discussed at the DOE conference reviewed in Section 2.4 above. They are composed of people who share interests and expertise. Strong KVCs are required for the advancement of any area of practice because KVCs provide fora for the exchange of ideas, sharing of research results, peer review of proposed projects and academic articles, and training of students and new KVC members. The achievements of strong KVCs can positively impact each other and become more than the sum of each individual activity and each individual effort. All of these projects brought new people into the respective $\mathrm{KVCs}$ and increased interactions among these people. The projects also engendered renewed focus on these areas of practice, contributing greatly to making the United States more internationally competitive in these areas. The rapid tooling process is being used by 
one of the Big 3 automakers, and the documentation produced from the durability of composite structures project is being directly or indirectly used by all three auto makers. 


\section{ACKNOWLEDGMENTS}

We wish to acknowledge the constructive critiques of earlier versions of this report provided by: Kimberly Davis, Santa Falcone, Beth Fitzsimmons, Richard C. Feiock, Albert Link, Michael McKee, Kelly Brown Maguire, Beryl A. Radin, and Dianne Rahm. Their comments were particularly helpful, although the authors are responsible for any errors or omissions. We wish to thank Louis Allen and Constance Griffith for their administrative and editorial assistance. 



\section{REFERENCES}

American Foundry Society, Inc. (AFS) 2001. "Design and Product Optimization for Cast Light Metals," final project report, Oct. Des Plaines, IL 60016-8399. Available: http://www.afsinc.org/ (May 2, 2002).

Alston, J. M., G. W. Norton and P. G. Pardey. 1995. Science Under Scarcity: Principles and Practice for Agricultural Research Evaluation and Priority Setting. Cornell University Press, Ithaca, NY.

Alston, J. M. and E. D. Beach. 1996. "Market Distortions and the Benefits from Research into New Uses for Agricultural Commodities: Ethanol from Corn.” Resource and Energy Economics 18, pp. 1-29.

Ammons, D. N. 1995. Accountability for Performance: Measurement and Monitoring in Local Government. International City/County Management Association, Washington, DC.

Automotive Composites Alliance (ACA). 2000. 2000 Model Year Passenger Car and Truck Thermoset Composite Components. Rochester, Michigan. Available: http://www.autocomposites.org/ (May 2, 2002). Accessed 5/02.

Babbie, E. 1998. The Practice of Social Research, $8^{\text {th }}$ edition. Wadsworth Publishing Company, Belmont, CA.

Bozeman, B. 1993. "Peer Review and Evaluation of R\&D Impacts." In Evaluating $R \& D$ Impacts: Methods and Practice. Eds. B. Bozeman and J. Melkers. Kluwer Academic Publishers, Boston, MA.

Bozeman, B. and J. Melkers, Eds. 1993. Evaluating R\&D Impacts: Methods and Practice. Kluwer Academic Publishers, Boston, MA.

Bralower, P. M. 1998. "Rapid Tooling Success: 7-1/2 Weeks from Database to Prototype Part." Die Casting Engineer 42, No. 5, Sept-Oct.

Brown, M. A., et.al. 1994. The Economic, Energy, and Environmental Impacts of the EnergyRelated Inventions Program. ORNL/CON-381. Oak Ridge National Laboratory, Oak Ridge, TN. 
Brown, M. A. and C. R. Wilson. 1993. "R\&D Spinoffs: Serendipity vs. A Managed Process.” Technology Transfer, 18, Nos. 3-4, Summer-Fall.

Brown, E. A. 1996. Applying the Principles of the Government Performance and Results Act to the Research and Development Function: A Case Study submitted to the Office of Management and Budget by the Army Research Laboratory. The Congressional Institute, Washington, DC. Available: http://www.conginst.org/resultsact/reports/ReportResearchDevelopment/casearl.html (June 12, 2001).

Brown, K. M. 1998. Downsizing Science: Will the United States Pay a Price? The AEI Press, Washington, DC.

Chapman, R. C. and S. K. Fuller. 1996. Benefits and Costs of Research: Two Case Studies in Building Technology. NISTIR 5840. U.S. Department of Commerce, Technology Administration, National Institute of Standards and Technology, Gaithersburg, MD. July.

Chapman, R. C. 1999. Benefits and Costs of Research: A Case Study of Cybernetic Building Systems. NISTIR 6303. U.S. Department of Commerce, Technology Administration, National Institute of Standards and Technology, Gaithersburg, MD. March.

Chapman, R. C. 2000. Benefits and Costs of Research: A Case Study of Construction Systems Integration and Automation Technologies in Industrial Facilities. NISTIR 6501. U.S. Department of Commerce, Technology Administration, National Institute of Standards and Technology, Gaithersburg, MD. June.

Composites Technology. 2001. “Automotive Market Will Drive Increased Composites Use, Say Two Sources.” Mar./Apr., p. 10.

Das, S. 2000. "The Life-Cycle Impacts of Aluminum Body-in-White Automotive Material." Journal of Metals. August, pp. 40-44.

Das, S., J. H. Peretz and B. E. Tonn. 2001. Evaluation of the Benefits Attributable to Automotive Lightweight Material Program Research and Development Projects. ORNL/TM-2001237. Oak Ridge National Laboratory, Oak Ridge, TN.

Dietz, F. 1997. “Government Partnerships Benefit Small Businesses.” Mechanical Engineering 199, No. 11, pp. 36-37. November. 
Ducker Research Company (DRC) 1998. "1999 Aluminum Content in North American Vehicles," Report ALW001. Nov. Bloomfield Hills, Michigan. Available: http://www.ducker.com/i_alum.htm (May 2, 2002).

Energy Information Administration (EIA) 2001. Available: http://www.eia.doe.gov/oiaf/aeo.html (May 2, 200). U.S. Department of Energy, Washington, DC.

Ernst, H. 1998. "Industrial Research as a Source of Important Patents.” Research Policy 29, pp. 1-15.

Fischer, F. 1995. Evaluating Public Policy. Nelson-Hall Publishers, Chicago, IL.

Fitzsimmons, C. B. 2001. "Knowledge Spillovers from Joint Government-Industry Supported Research: A Case-Study from the Automotive Industry." Ph.D. dissertation, George Mason University, Fairfax, Virginia. Spring.

Geisler, E. 1995. "An Integrated Cost-performance Model of Research and Development Evaluation.” Omega, International Journal of Management Science 23, No. 3, pp. 281294.

Gelijns, A., N. Rosenberg and A. J. Moskowitz. 1998. "Capturing the Unexpected Benefits of Medical Research.” New England Journal of Medicine 399, No. 10, September 3, pp. 693-698.

Gibson, D. V. and E. M. Rogers. 1994. R\&D Collaboration on Trial: The Microelectronics and Computer Technology Corporation. Harvard Business School Press, Boston, MA.

Griliches, Z. 1998. R\&D and Productivity: The Econometric Evidence. University of Chicago Press, Chicago, IL.

Hamilton, S. F. and D. L. Sunding. 1998. "Returns to Public Investments in Agriculture with Imperfect Downstream Competition." American Journal of Agricultural Economics 80, November, pp. 830-838.

Hendrick, R. 1994. "An Information Infrastructure for Innovative Management of Government." Public Administration Review. 54, No. 6, pp. 543-549, November/December.

Hyde, W. F., D. H. Newman and B. J. Seldon. 1992. The Economic Benefits of Forestry Research. Iowa State University Press, Ames, IA. 
Kanicki, D. P. 2000. “Global Casting Report: Past, Present \& Future," Modern Casting December, pp. 24-27. Available: http://www.moderncasting.com/ (May 2, 2002).

Kingsley, G. 1993. "The Use of Case Studies in R\&D Impact Evaluations." In Evaluating $R \& D$ Impacts: Methods and Practice. Eds. B. Bozeman and J. Melkers. Kluwer Academic Publishers, Boston, MA.

Kirgin, K.H. and M.J. Lessiter. 2002. “U.S. Metal Casting Demand \& Supply Trends - 2002," Engineered Cast Solutions. Winter, pp. 25-28. Available: http://www.castsolutions.com/archive/08.2_01_feature_article.html (May 2, 2002).

Langbein, L. I. 1980. Discovering Whether Programs Work: A Guide to Statistical Methods for Program Evaluation. Scott, Foresman and Company, Glenview, IL.

Lee, R. et. al. 2002. Ideas on a Framework and Methods for Estimating the Benefits of Government-Sponsored Energy $R \& D$. Draft prepared as pre-conference reading material for conference on "Estimating the Benefits of Government-Sponsored Energy R\&D." Oak Ridge National Laboratory, Oak Ridge, TN.

Leiby, P.N. et al. 1997. Oil Imports: An Assessment of Benefits and Costs. ORNL-6851. Oak Ridge National Laboratory, Oak Ridge, TN. November.

Link, A. N. 1993. "Methods for Evaluating the Return on R\&D Investments." In Evaluating $R \& D$ Impacts: Methods and Practice. Eds. B. Bozeman and J. Melkers. Kluwer Academic Publishers, Boston, MA.

Link, A. N. 1995. "Evaluating Program Performance: The Case of Federally-funded Collaborative Research." International Journal Technology Management 10, No. 7/8, pp. 847-852.

Link, A. N., D. J. Teece and W. F. Finan. 1996. "Estimating the Benefits from Collaboration: The Case of SEMATECH.” Review of Industrial Organization. 11, pp. 737-751.

Link, A.N. 1997. "Advanced Technology Program: Early Stage Impacts of the Printed Wiring Board Research Joint Venture, Assessed at Project End." Washington, DC: U.S. Department of Commerce, National Institute of Standards and Technology, NIST GCR 97-722.

Link, A. N. and J. T. Scott. 1998. Public Accountability: Evaluating Technology-Based Institutions. Kluwer Academic Publishers, Boston, MA. 
MacRae, Duncan, Jr. and Dale Whittington. 1997. Expert Advice for Policy Choice: Analysis and Discourse. Washington, DC: Georgetown University Press.

Mansfield, E. 1995. Innovation, Technology and the Economy: Selected Essays of Edwin Mansfield (2 volumes) Economists of the Twentieth Century Series, Elgar Publishers, Aldershot, United Kingdom.

Martin, S. A., M. P. Gallager and A. C. O'Connor. 2000. Economic Impact of Standard Reference Materials for Sulfur in Fossil Fuels. NIST Report No. 00-1, RTI Project Number 7007-006. Report prepared by Research Triangle Institute, Research Triangle Park, North Carolina, for National Institute of Standards and Technology. February.

Marx, M. L., J. T. Scott and S. M. Fry. 2000. Economic Impact Assessment: NIST-EEEL Laser and Fiberoptic Power and Energy Calibration Services. NIST 00-3. Report prepared by TASC, Inc., Arlington, Virginia, for National Institute of Standards and Technology. August.

Melkers, J. 1993. "Bibliometrics as a Tool for Analysis of R\&D Impacts." In Evaluating $R \& D$ Impacts: Methods and Practice Eds. B. Bozeman and J. Melkers. Kluwer Academic Publishers, Boston, MA.

Mowery, D. C. and R. R. Nelson. 1999. Sources of Industrial Leadership: Studies of Seven Industries. Cambridge University Press, Cambridge, UK.

National Academy of Sciences (NAS). 1999. Evaluating Federal Research Programs: Research and the Government Performance and Results Act. National Academy Press, Committee on Science, Engineering, and Public Policy, Washington, DC.

National Academy of Sciences (NAS). 2001a. Energy Research at DOE Was it Worth it? Energy Efficiency and Fossil Energy Research 1978 to 2000. National Academy Press, Committee on Benefits of DOE R\&D on Energy Efficiency and Fossil Energy, Washington, DC.

National Academy of Sciences (NAS). 2001b. Review of the Research Program of the Partnership for a New Generation of Vehicles: Seventh Report. National Academy Press, Committee to Review the Research Program of the Partnership for a New Generation of Vehicles, Board on Energy and Environmental Systems, Transportation Report Board, Washington, DC. 
National Research Council. 1994. Organizational Linkages: Understanding the Productivity Paradox. National Academy Press, Washington, DC.

Nelson, R. R., J. Peck and E. D. Kalachek. 1967. Technology, Economic Growth, and Public Policy. The Brookings Institution, Washington, DC.

Nelson, R. R. and S. G. Winter. 1982. An Evolutionary Theory of Economic Change. Harvard University Press, Cambridge, MA.

Office of Management and Budget, The White House. January 1996 "Economic Analysis of Federal Regulations Under Executive Order 12866.” Washington, DC: OMB. http://www.whitehouse.gov/omb/inforeg/riaguide.html. accessed 7/22/02.

Papadakis, M. and A. N. Link. 1997. "Measuring the Unmeasurable: Cost-Benefit Analysis for New Business Start-ups and Scientific Research Transfers." Evaluation and Program Planning 20, No. 1, pp. 91-102.

Posavac, E. J. and R. G. Carey. 1985. Program Evaluation: Methods and Cases (2 ${ }^{\text {nd }}$ edition). Prentice-Hall, Inc., Englewood Cliffs, NJ.

Radin, B. A. 1998. "The Government Performance and Results Act (GPRA): Hydra-Headed Monster or Flexible Management Tool?" Public Administration Review 58, No. 4, July/August, pp. 307-315, July/August.

Riggert, Jeff et al. 1999. "An Evaluation of the Energy and Non-energy Impacts of Vermont's Weatherization Assistance Program." TecMRKT Works, Oregon, WI. November. Available: http://www.tecmrkt.com/ (May 2, 2002).

Rossi, P. H. and H. E. Freeman. 1985. Evaluation: A Systematic Approach (3 ${ }^{\text {rd }}$ edition). Sage Publications, Inc., Beverly Hills, CA.

Rouse, W. B., K. R. Boff and B. G. Sutley Thomas. 1997. "Assessing Cost/Benefits of Research and Development Investments." IEEE Transactions on Systems, Man, and Cybernetics 27, No. 4, July, pp. 389-401.

Rusnak, A. 2002. “Automotive Industry Increases Composites Use for 2002: Trends Toward Style," Composites Fabrication 18, No. 4, April, pp. 27-29. 
Scherer, F. M. 1965. "Government Research and Development Programs.” In Measuring Benefits of Government Investments. Ed. Robert Dorfman. The Brookings Institution, Washington, DC.

Schultz, R. A. 1999. “Aluminum for Lightweight Vehicles: An Objective Look At The Next 10 to 20 Years," presented at the Metal Bulletin $14^{\text {th }}$ International Aluminum Conference, Montreal, Canada, Sept. 15. Available from Richard A. Schultz, Ducker Research Co., Inc.

Schultz, R. A. 2001. “A Realistic Assessment of Future Worldwide Aluminum Use," presented at Commodity Metals Management Aluminum Trends Seminar, Naples, France, Apr. 3.

Torpey, P. J. 1994. “Collaborative R\&D Helps Companies Stay Competitive.” Mechanical Engineering. 116, No. 10, October, pp. 85-86.

Twarog, D. L. 2001. "State of the Industry.” Die Casting Engineer. February, pp. 22-30. Available: http://www.diecasting.org/dce/archive/login.asp (May 2, 2002).

Udvardy, S. 2001. North America Die Casting Association, Rosemont, IL, personal communication with Sujit Das on 11/20/01.

U. S. Congress. 1993. Government Performance and Results Act of 1993. Pub. L 103-62.

U.S. Department of Energy (DOE). 2002. Impacts: Office of Industrial Technologies: Summary of Program Results, Methodology for Technology Forecasting and Assessment of Benefits. Office of Industrial Technologies, Washington, DC., pp. 169-171. http://www.pnl.gov/impacts. accessed 7/22/02.

U.S. General Accounting Office (GAO). 1997. Measuring Performance: Strengths and Limitations of Research Indicators. GAO/RCED-97-91. GAO, Washington, DC. March.

United States Council for Automotive Research. Available: http://www.uscar.org/index.htm and http://www.uscar.org/uscar/uscarmain.htm (May July 22, 2002).

Yin, R. K. 1984. Case Study Research: Design and Methods. Sage Publications, Beverly Hills, CA. 
Yuracko, K., B. Tonn and M. Morris. 1999. Assessment of Cost Savings of DOE's Return-onInvestment Program. ORNL/TM-1999/155. Oak Ridge National Laboratory, Oak Ridge, TN. 
APPENDIX A 


\section{Methods for Conducting Program Evaluations.}

1. Economics. In addition to the traditional benefit-cost ratios, a more recently used economic measure gauges how much private sector investment is needed to achieve a certain level of technical capability. It seeks a response to "In the absence of . . . [federal funding] . . , what would your company have had to do to obtain the same level of technical capability that it currently has, and what resources over what time period would have been needed to pursue such an alternative" (Link and Scott, 1998, page 14).

For more on the use of economics methods for evaluating federal R\&D and weaknesses as a methodology, see NAS, 1999; U.S. GAO, 1997; Link, 1993; Rouse, Boff and Thomas, 1997; Brown, 1998.

2. Bibliometrics. The use of bibliometrics has been accepted as a proxy for R\&D benefits because of the difficulties in evaluating R\&D activities (Melkers, 1993). Bibliometrics can serve as a source of information on "measurement of scientific output, the extent of knowledge transfer and the impact of research, and an approximation of the links between science and technology" (Melkers, 1993, page 49). Its use has been expedited by the creation of the Science Citation index.

These metrics serve as a quantitative, well understood proxy for how the research is viewed. Use of bibliometrics is based on the assumption that a researcher's work is valuable when judged so by a researcher's peers. Acceptance of a peer-reviewed paper occurs after a traditionally rigorous evaluation process of its merit. Citation counts can appear in patent applications, as well as other research in the field. Patents can show a nation's technological strength and are a signal of innovation from an R\&D project. Brown (1998) reports a strong relationship between scientific papers cited on patent applications and federally funded R\&D.

3. Case studies. Case studies clearly identify qualitative issues, such as degree of collaboration, training for junior researchers, and the dynamics within a specific setting that can be used to judge success. A commonly cited justification for using case studies as a research method in general is due to a lack of clearly understood theory to associate with results. Specifically, for $R \& D$, the uncertainty lies in how different types of R\&D projects affect economic growth (Yin, 1984; Kingsley, 1993).Case studies of federal R\&D and economic growth became popular in the 1960s. Case studies can be expensive to conduct, clearly a limitation to their extended use.

4. Peer reviews. Peer review is a self-evaluation in the sense that reviewers come from the researcher's primary disciplinary field. Its premise is that those most knowledgeable in the field can gauge research agendas and the qualifications of those conducting the research. Who is defined as an expert can raise questions about bias and favoritism. For example, the Committee on Science Engineering, and Public Policy (COSEPUP) of the National Research Council was 
asked to review how federal agencies should respond to GPRA's performance requirements on R\&D projects. COSEPUP's report, which emphatically recommends the use of peer review (or expert review) when evaluating government R\&D programs, noted that "legitimate concerns ... have been raised about expert review (such as conflict of interest, independence, and elitism)" (NAS, 1999, pages 32-33). 

APPENDIX B 
Benefits Matrix for the PNGV Program ${ }^{a}$

\begin{tabular}{|c|c|c|c|}
\hline & Realized Benefits/Costs & Options Benefits/Costs & Knowledge Benefits/Costs \\
\hline $\begin{array}{l}\text { Economic } \\
\text { benefits/costs }\end{array}$ & $\begin{array}{l}\text { DOE cost (1995-1999) approximately } \\
\$ 371 \text { million. Total federal funding } \\
\text { approximately } \$ 1.3 \text { billion. Industry } \\
\text { cost share: substantial for } \\
\text { indeterminate. } \\
\text { Lightweight materials are generally } \\
\text { more expensive than steel, giving } \\
\text { negative economic benefits. } \\
\text { However, improved manufacturing } \\
\text { processes, fuel savings, and reduction } \\
\text { in subcomponents can sometimes } \\
\text { compensate for higher material costs. } \\
\text { (For example, the Chevrolet pickup } \\
\text { bed has a positive economic benefit, } \\
\text { as much as } 2 \% \text {, if compared with } \\
\text { steel at annual volumes less than } \\
75,000, \text { but a negative benefit at } \\
\text { higher volumes due to tooling } \\
\text { replacement. Customer saves about } \\
\$ 12 \text { in fuel cost per year. Benefit is } \\
\text { positive if compared with a } \\
\text { composite aftermarket liner.) } \\
\text { Some manufacturing technologies in } \\
\text { use have positive economic benefits } \\
\text { (e.g., welding, forming, drilling, } \\
\text { springback). }\end{array}$ & $\begin{array}{l}\text { When eventually applied, option } \\
\text { economic benefits will be positive for } \\
\text { the following: } \\
\text { (1) Improved body structure } \\
\text { (2) Design } \\
\text { (3) Manufacturing technologies: (a) } \\
\text { casting, (b) painting, (c) ion- } \\
\text { implantation, (d) induction heating, } \\
\text { (e) adhesive bonding } \\
\text { (4) Rapid prototyping } \\
\text { (5) Combustion diagnostics } \\
\text { (6) Phosphor thermometry } \\
\text { (7) Simulation/modeling } \\
\text { (8) Virtual reality } \\
\text { (9) Recycling } \\
\text { Because they appear to be more } \\
\text { expensive than the corresponding } \\
\text { conventional technologies they } \\
\text { replace, when and if eventually } \\
\text { applied to automobiles, option } \\
\text { economic benefits may be negative } \\
\text { for the following: } \\
\text { (1) Hybrid power train } \\
\text { (2) High-power batteries }{ }^{b} \\
\text { (3) Materials (a) Ni-aluminide dies } \\
\text { (b) diamond-like coatings } \\
\text { (4) Lightweight airbag } \\
\text { (5) Hybrid power train technology } \\
\text { (6) High-power batteries }{ }^{b} \\
\text { (7) Materials (a) Ni-aluminide dies } \\
\text { (b) diamond-like coatings } \\
\text { (8) lightweight airbag }\end{array}$ & $\begin{array}{l}\text { Gaining knowledge collaboratively } \\
\text { reduces duplication of effort and } \\
\text { corresponding cost. } \\
\text { Recycling } \\
\text { Gas turbines/ceramics } \\
\text { Fuel cells } \\
\text { Fuel reformers } \\
\text { Stirling engines } \\
\text { Exhaust catalysts } \\
\text { (a) plasma treated } \\
\text { (b) vacuum insulated } \\
\text { (c) lean burn } \\
\text { Lightweight engines } \\
\text { Alternative fuels } \\
\text { High-power energy storage } \\
\text { (a) highpower batteries }{ }^{\mathrm{b}} \\
\text { (b) ultracapacitors } \\
\text { (c) flywheels } \\
\text { (d) pneumatic/hydraulic } \\
\text { Power electronics } \\
\text { Diesel injection pump } \\
\text { Diesel emission control } \\
\text { Modified diesel fuel } \\
\text { Variable compression ratio engine } \\
\text { Air conditioners } \\
\text { Lightweight interiors } \\
\text { Aerodynamic drag }\end{array}$ \\
\hline $\begin{array}{l}\text { Environmental } \\
\text { benefits/costs }\end{array}$ & $\begin{array}{l}\text { Reduced weight gives improvement } \\
\text { in fuel economy and reduced } \mathrm{CO}_{2} \\
\text { emission. } \\
\text { Pickup bed gives } 1.3 \% \text { vehicle } \\
\text { weight reduction, or } 0.18 \mathrm{mpg} \text { fuel } \\
\text { economy improvements }\end{array}$ & $\begin{array}{l}\text { Reduced weight and more efficient } \\
\text { vehicle gives improvement in fuel } \\
\text { economy and reduced } \mathrm{CO}_{2} \text { emissions }\end{array}$ & $\begin{array}{l}\text { Reduced weight and more efficient } \\
\text { vehicle that meets emission } \\
\text { requirements gives improvement in } \\
\text { fuel economy and reduced } \mathrm{CO}_{2} \\
\text { emissions. }\end{array}$ \\
\hline $\begin{array}{l}\text { Security } \\
\text { benefits/costs }\end{array}$ & $\begin{array}{l}\text { Same as environmental } \\
\text { Improved fuel economy reduces } \\
\text { demand for imported oil. }\end{array}$ & $\begin{array}{l}\text { Same as environmental } \\
\text { Improved fuel economy reduces } \\
\text { demand for imported oil. }\end{array}$ & $\begin{array}{l}\text { Same as environmental } \\
\text { Improved fuel economy reduces } \\
\text { demand for imported oil. } \\
\text { Knowledge applicable to military use. }\end{array}$ \\
\hline
\end{tabular}

${ }^{\text {a }}$ Unless otherwise noted, all dollar estimates are given in constant 1999 dollars through 2000.

${ }^{\mathrm{b}}$ Separate cases for this technology were conducted by NAS (2001).

Source: NAS, 2001a, Appendix E, page 148 


\section{INTERNAL DISTRIBUTION}

$\begin{array}{ll}\text { 1. } & \text { D. J. Bjornstad } \\ 2 . & \text { M. A. Brown } \\ \text { 3-17. } & \text { S. Das } \\ 18 . & \text { E. C. Fox } \\ \text { 19. } & \text { D. L. Greene } \\ 20 . & \text { E. T. Grostick } \\ 21 . & \text { H. E. Knee } \\ 22 . & \text { R. Lee }\end{array}$
23.
P. S. Sklad
24.
B. E. Tonn
25.
26.
C. D. Warren
27.
R. E. Ziegler
28-29.
Central Research Library
30 .
ORNL Laboratory Records-OSTI
ORNL Laboratory Records-RC

\section{EXTERNAL DISTRIBUTION}

31. Amcast Automotive, 300 Galleria Office Center, Suite 208, Southfield, MI 48034

32. Mr. Richard Berkmortel, PE, Meridian Technologies Inc., Global Technology Centre, $25 \mathrm{MacNab}$ Avenue, Strathroy, Ontario N7G 4H6 Canada

33. Dr. Joe Carpenter, Office of Transportation Technologies, Energy Efficiency \& Renewable Energy, U.S. Department of Energy, 5G-030/FORS, 1000 Independence Ave., S.W., Washington, DC 20585-0121

34. Dr. Gerald S. Cole, 25800 Romany Way, Franklin, MI 480235-1197

35. James M. Corum, Oak Ridge National Laboratory, Bldg. 9204-1, M. S. 8051, Oak Ridge, Tennessee 37831-8051

36. Mr. Thomas J. Dearlove, GM R\&D Center, MC: 480-106-224, 30500 Mound Road, Warren, MI 48090-9055

37. Douglas L. Denton, CIMS 429-18-04, DaimlerChrysler, 2301 Featherstone Road, Auburn Hills, MI 48326

38. Ms. Sara A. Dillich, Office of the Industrial Technology, U.S. Dept. of Energy, 5F-035/FORS, 1000 Independence Ave., S. W., Washington, DC 20585-0121

39. Mr. Robert E. Eppich, Eppich Technologies, P.O. Box 1003, Port Lavaca, Texas 77979 
40. Mr. Kenneth M. Friedman, Office of Program Budget and Financial Analysis, U.S. Dept. of Energy, 5F-065/FORS, 1000 Independence Ave., S. W., Washington, DC 20585-0121

41. Mr. Gerald Gegel, Caterpillar Inc., Technical Center, TC-e/854, P.O. Box 1875, Peoria, IL 616561875

42. Mr. Vincent J. Genise, Citation-Automotive Sales \& Engr. Div., 27275 Haggerty Road No. 420, Novi, MI 48377-3635

43. C. W. "Tony” Hirt, Ph.D., Flow Science Inc., 683 Harkle Road, Suite A, Santa Fe, NM 87505

44. Dan Houston, 22751 Hollander, Dearborn, Michigan 48128

45. Chung-Whee Kim, Ph.D, EKK, 100 North Pond Drive, Suite A, Walled Lake, MI 48390

46. Fred Major, Alcan International Lmd., Kingston R\&D Centre, P.O. Box 8400, Kingston, Ontario K7L, 5L9 Canada

47. Mr. Philip D. Patterson, Jr., Office of the Planning, Budget Formulation \& Analysis, U.S. Dept. of Energy, 1000 Independence Ave., S. W., Washington, DC 20585-0121

48. Mr. D.E. Penrod, PE , Manufacturing Services \& Development, Inc., 4665 Arlington Rd., Cape Haze, FL 33946

49. J. H. Peretz, The University of Tennessee, Energy, Environment and Resources Center, 311 Conference Center Building, 600 Henley Street, Knoxville, TN 37996-4134

50. Mr. Pete Pollack, The Aluminum Association, $90019^{\text {th }}$ Street, NW, Washington, DC 20006-2168

51. Mr. Thomas Prucha, Intermet Corporation, 5445 Corporate Drive, Suite 200, Troy, MI 48098

52. Mr. Larry Quimet, GM Powertrain MC - 481-700-900, Ypsilanti Transmission Plant, Ecorse and Wiard Roads, Ypsilanti, Michigan 48197-0935

53. Mr. Robert L. Uhrman, GM/Saturn Corporation, Powertrain J-15, 100 Saturn Parkway, Spring Hill, TN 37174

54. Mr. Greg Sanders, ENTELECHY, 42325 Ann Arbor Road, Suite 220, Plymouth, MI 48170-4356

55. Dr. Joseph S. Santner, American Foundry Society, 505 State Street, Des Plaines, Il 60016-8399 
56. Richard A. Schultz, Ducker Research Company, Inc., 6905 Telegraph Road, Bloomfield Hills, MI 48301

57. Dr. Shaupoh Wang, AEMP Corporation, 2404 Dr. F.E. Wright Drive, Jackson, TN 38305

58. Gary Ward, GM Powertrain MC - 481-700-900, Ypsilanti Transmission Plant, Ecorse and Wiard Roads, Ypsilanti, Michigan 48197-0935

59. Mr. David Weiss, ECK Industries, P.O. Box 967, Manitowoc, WI 54221-0967

60. Mr. Walter Winterbottom, AEMP Corporation, 2404 Dr. F.E. Wright Drive, Jackson, TN 38305

61. Mr. Greg Woycik, Hayes Lemmerz, HLI Technical Center, 1600 West Eight Mile Road, Ferndale, MI 48220 